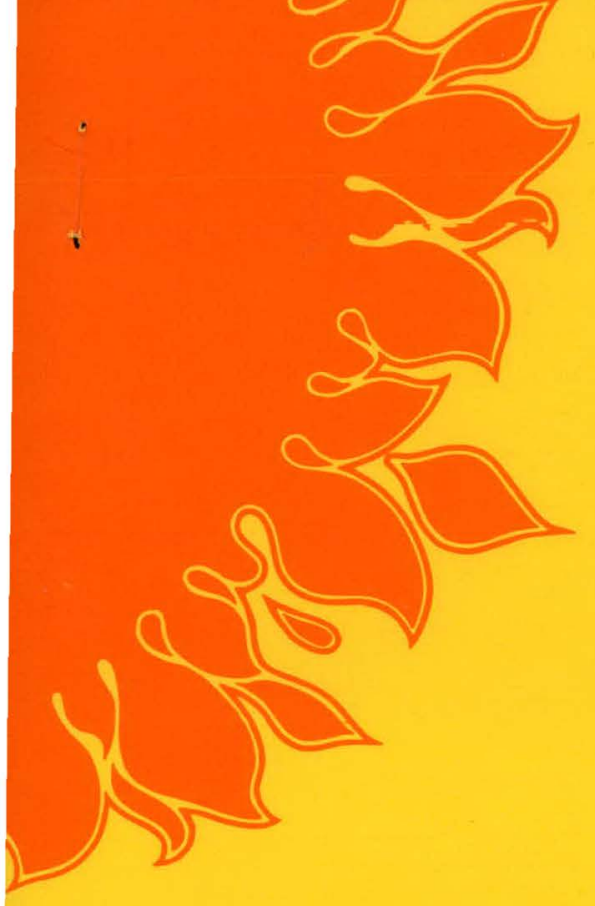

ERDA/JPL/954373-76/4

\title{
HEAT EXCHANGER-INGOT CASTING/SLICING PROCESS. \\ SILICON SHEET GROWTH DEVELOPMENT FOR THE LARGE AREA \\ SILICON SHEET TASK OF THE LOW COST SILICON SOLAR ARRAY PROJECT
}

Fourth Quarterly Progress Report, June 19, 1976-September 24, 1976

\author{
F. Schmid \\ B. Reynolds
}

September 24, 1976

Work Performed Under Contract No. NAS-7-100-954373

Crystal Systems, Incorporated

Salem, Massachusetts

\section{ENERGY RESEARCH AND DEVELOPNEHT}

\section{Division of Solar Energy}




\section{DISCLAIMER}

This report was prepared as an account of work sponsored by an agency of the United States Government. Neither the United States Government nor any agency Thereof, nor any of their employees, makes any warranty, express or implied, or assumes any legal liability or responsibility for the accuracy, completeness, or usefulness of any information, apparatus, product, or process disclosed, or represents that its use would not infringe privately owned rights. Reference herein to any specific commercial product, process, or service by trade name, trademark, manufacturer, or otherwise does not necessarily constitute or imply its endorsement, recommendation, or favoring by the United States Government or any agency thereof. The views and opinions of authors expressed herein do not necessarily state or reflect those of the United States Government or any agency thereof. 


\section{DISCLAIMER}

Portions of this document may be illegible in electronic image products. Images are produced from the best available original document. 


\section{NOTICE}

This report was prepared as an account of work sponsored by the United States Government. Neither the United States nor the United States Energy Research and Development Administration, nor any of their employees, nus any of their contractors, subcontractors, or their employees, makes any warranty, express or implied, or assumes any legal liability or responsibility for the accuracy, completeness or usefulness of any information, apparatus, product or process disclosed, or represents that its use would not infringe privately owned rights.

This report has been reproduced directly from the best available copy.

Available from the National Technical Information Service, U. S. Department of Commerce, Springfield, Virginia 22161

Price: Paper Copy $\$ 4.50$ (domestic) $\$ 7.00$ (foreign)

Microfiche $\$ 3.00$ (domestic)

$\$ 4.50$ (foreign) 


\title{
HEAT EXCHANGER-INGOT CASTING/SLICING PROCESS
}

Silicon Sheet Growth Development for the Large Area Silicon Sheet Task of the Low Cost Silicon Solar Array Project

\author{
Fourth Quarterly Progress Report \\ by \\ Frederick Schmid and Blake Reynolds \\ Covering Period from June 19, 1976, to September 24, 1976 \\ Date of Report: September 24, 1976 \\ JPL Contract No. 954373
}
CRYSTAL SYSTEMS, INC. 35 Congress Street P. 0. Box 1057
Salem, MA 01970

This work was performed for the Jet Propulsion Laboratory, California Institute of Technology; under NASA Contract NAS7-100 for the U. S. Energy Research and Development Administration, Division of Solar Energy.

The JPL Low-Cost Silicon Solar Array Project is funded by ERDA and forms part of the ERDA Photovoltaic Conversion Program to initiate a major effort toward the development of low-cost solar arrays. 
TABLE OF CONTENTS

ABSTRACT ................... . . $i$ QÚARTERLY SILICON PROGRESS . . . . . . . . . . . 1

General Discussion . . . . . . . . . . . . 1

Silicon Seeding and Growth . . . . . . . 21

Ingot Cracking . . . . . . . . . . . 23

Impurity Pickup. . . . . . . . . . . . 25

Temperature Control. . . . . . . . . 27

SILICON CRYSTAL SLICING. . . . . . . . . . 29

Summary. . . . . . . . . . . . . 29

Slicing Testing............. 29

Blade Characterization . . . . . . . . . 34

Machine Calibration. . . . . . . . 34

Data Reduction ............. . 34

Slicing Procedure............ . 35

Results and Discussion . . . . . . . . . . 35

Slicing Testing .......... . . 35

Discussion - Run 2B. ........... 36

Discussion - Runs 1, 2, 2B, 3, 4, 5, 5B. ... 44

Discussion - Run 6 .......... . . 53

Slicing Procedure. . . . . . . . . . 54

CONCLUSIONS . • • • • • • • • . • • • • 57

REFERENCES .................. 62 
This report contains information prepared by Crystal Systems, Inc., under JPL subcontract. Its content is not necessarily endorsed by the Jet Propulsion Laboratory, California Institute of Technology, or the National Aeronautics and Space Administration, or the U. S. Energy Research and Development Administration, Division of Solar Energy .

MAN-HOURS AND COST TOTALS

$\underline{\text { Previous }}$

$\mathrm{M} / \mathrm{Hr}$. Cost

$2,113 \$ 112,656$

\section{Current}

$\mathrm{M} / \mathrm{Hr}$. Cost

$1,148 \$ 50,030$
Cumulative

$\mathrm{M} / \mathrm{Hr}$. Cost

$3,261 \quad \$ 162,686$ 


\section{ABSTRACT}

Significant progress has been made in establishing good seeding and growth parameters. Good nucleation and growth from the seed were achieved by decreasing the melt superheat and increasing the heat-exchanger temperature. Single-crystal growth nucleates from the (111) seed and advances on the (111) in a pyramidal form. Contaminatior. at the seed/ingot interface outlines the interface. This does not cause breakdown of crystallinity but causes a distinct electrical change from $n$ - to p-type at the interface. The new-grown silicon has higher resistivity and becomes p-type due to the doping of the molten silicon by iron from the graphite heat zone. The new growth and silicon are of high crystal quality as evidenced by dislocation densities of approximately $100 / \mathrm{cm}^{2}$.

To achieve a high enough seeding temperature at superheat temperatures below $7^{\circ} \mathrm{C}$, the heat exchanger was raised one inch higher in the heat zone. For this position, seeding conditions had to be re-established since the temperature profile across the diameter of the heat zone was flatter. The uniform temperature across the diameter of the crucible allows not only for good seeding, but also for good growth. Crystal growth has been extended across the entire diameter 
of the crucible for this condition:

All ingots produced to date have cracked due to localized tension of the silicon at the silica crucible interface at about $650^{\circ} \mathrm{C}$. Silicon forms a bond that adheres tenaciously to the crucible. Fracturing occurs across the diameter of the ingot on (111) with secondary fracturing on (110).

Breakdown of the planar growth interface occurred when the liquid gradient was too low; this delineated the shape of the interface.

For crystal slicing, cutting rates of from 1 to 4 $\mathrm{mil} / \mathrm{min}$ were anhieved for feed forces from 0.05 to 0.25 lbf/blade. Cutting rate was heavily dependent on diamond concentration. Low cutting rates and blade damage occurred for diamond impregnated wire with low and non-uniform diamond concentrations.

Crystal Systems has charged copper-plated wire with $45 \mu$ diamond. These wires had high cutting rates of over $4 \mathrm{mil} / \mathrm{min}$. Some wires were not charged adequately, causing blade damage.

Degradation of cutting rate appears to occur more rapidly at higher feed force. This is currently being related to diamond pull out and wear. 


\section{QUARTERLY PROGRESS}

\section{SILICON CRYSTAL CASTING}

Good seeding and growth were achieved during the past quarter with the Heat Exchanger Method at melt superheats below $10^{\circ} \mathrm{C}$. To achieve a high enough seeding temperature at low superheat, the heat exchanger was raised one inch higher in the heat zone. For this higher position, seeding conditions had to be re-established since the temperature profile across the diameter of the heat zone was flatter; i.e., the temperature in the middle of the heat zone was closer to the temperature near the heating element. The furnace temperature at the level of the heat exchanger was higher and, therefore, the heat-exchanger temperature had to be lower for equal superheat temperatures. The experiments that were conducted at lower superheat temperatures showed that the optical-pyrometer readings on which our superheat temperatures were previously based varied as much as $\pm 5^{\circ} \mathrm{C}$ depending on atmospheric conditions. A means for accurately determining the melt-point temperature was developed.

All the boules produced to date have cracked during . cool down, regardless of the annealing and cool-down cycle. 
The cracking appears to be due to the expansion mismatch between the silicon and the silica which are tenaciously bonded together. The tabulation of the heat-exchanger and furnace temperatures for this quarter's runs are presented in Table I.

\section{$\underline{\text { Run } 21}$}

Run 21 was designed to be run at $10^{\circ} \mathrm{C}$ melt superheat and $100^{\circ} \mathrm{C}$ heat exchanger undercooling. The melt was superheated $10^{\circ} \mathrm{C}$ according to the optical pyrometer on which control was based. An automatic-radiation pyrometer, however, indicated that the melt was superheated $20^{\circ} \mathrm{C}$. For this run the seed was melted out, indicating that the melt was superheated more than $10^{\circ} \mathrm{C}$.

Review of previous runs indicated that the automaticradiation pyrometer produced repeatable and accurate readings, but the optical-pyrometer reading varied with atmospheric conditions. It appeared to read lower on humid days and higher on dry days. A platinum/platinum-rhodium thermocouple was installed to act as a control. All superheat temperatures indicated in Table 1 are based on the automaticpyrometer readings, which have been checked for accuracy against the thermocouple readings.

\section{Run 22}

Run 22 was superheated $11^{\circ} \mathrm{C}$ with a $90^{\circ} \mathrm{C}$ heat exchanger 
TABLE I

TABULATION OF HEAT-EXCHANGER AND FURNACE TEMPERATURES

\begin{tabular}{|c|c|c|c|c|c|c|}
\hline RUN & PURPOSE & $\begin{array}{l}\text { SEE } \\
\text { FURN. } \\
\text { TEMP. } \\
\text { ABOVE M.P. } \\
\end{array}$ & $\begin{array}{l}\text { NG } \\
\text { H.E. TEMP. } \\
\text { BELOW M.P. }\end{array}$ & $\begin{array}{l}\text { RATE OF. GROY } \\
\text { H.E. TEMP. } \\
\end{array}$ & $\begin{array}{r}\text { RATE OF } \\
\text { FURN. TEMP. } \\
\end{array}$ & REMARKS \\
\hline 21 & $\begin{array}{l}\text { Decrease furnace } \\
\text { superheat and } \\
\text { slow initial } \\
\text { growth. }\end{array}$ & $20^{\circ} \mathrm{C}$ & $100^{\circ} \mathrm{C}$ & $\begin{array}{l}1^{\circ} \mathrm{C} / 1 \mathrm{st} \mathrm{hr} \\
98^{\circ} \mathrm{C} / 18 \mathrm{hr}\end{array}$ & $20^{\circ} \mathrm{C} / 19 \mathrm{hr}$. & $\begin{array}{l}\text { Seed melted } \\
\text { out; large } \\
\text { columinar grains. }\end{array}$ \\
\hline 22 & $\begin{array}{l}\text { Decrease furnace } \\
\text { superheat. } \\
\text { Increase } \mathrm{H} . \text { E. } \\
\text { temperature. }\end{array}$ & $11^{\circ} \mathrm{C}$ & $90^{\circ} \mathrm{C}$ & $\begin{array}{l}4^{\circ} \mathrm{C} / 1 \text { st } \mathrm{hr} \\
56^{\circ} \mathrm{C} / 21 \mathrm{hr} .\end{array}$ & $11^{\circ} \mathrm{C} / 22 \mathrm{hr}$. & $\begin{array}{l}\text { Good seed melt- } \\
\text { back and seed- } \\
\text { ing. Seed, inter- } \\
\text { face not apparent }\end{array}$ \\
\hline 23 & $\begin{array}{l}\text { Decrease furnace } \\
\text { superheat. } \\
\text { Increase H.E. } \\
\text { temperature. }\end{array}$ & $7^{\circ} \mathrm{C}$ & $80^{\circ} \mathrm{C}$ & $\begin{array}{l}8^{\circ} \mathrm{C} / 1 \text { st hr. } \\
84^{\circ} \mathrm{C} / 18 \mathrm{hr} .\end{array}$ & $7^{\circ} \mathrm{C} / 19 \mathrm{hr}$ & $\begin{array}{l}\text { Good seed melt- } \\
\text { back and seed- } \\
\text { ing. }\end{array}$ \\
\hline 24 & $\begin{array}{l}\text { Decrease furnace } \\
\text { and H.E. } \\
\text { temperature. }\end{array}$ & $3^{\circ} \mathrm{C}$ & $80^{\circ} \mathrm{C}$ & $\begin{array}{l}7^{\circ} \mathrm{C} / 1 \text { st hr. } \\
47^{\circ} \mathrm{C} / 11 \mathrm{hr} .\end{array}$ & $3^{\circ} \mathrm{C} / 12 \mathrm{hr}$ & $\begin{array}{l}\text { No seed melt- } \\
\text { back. Some } \\
\text { growth off-top } \\
\text { edge of seed. }\end{array}$ \\
\hline 25 & $\begin{array}{l}\text { Decrease furnace } \\
\text { temperature and } \\
\text { and H.E. temp. }\end{array}$ & $8^{\circ} \mathrm{C}$ & $78^{\circ} \mathrm{C}$ & $\begin{array}{l}12{ }^{\circ} \mathrm{C} / 1 \text { st } \mathrm{hr} . \\
172{ }^{\circ} \mathrm{C} / 24 \mathrm{hr} .\end{array}$ & $8^{\circ} \mathrm{C} / 25 \mathrm{hr}$ & $\begin{array}{l}\text { Good seeding. } \\
\text { Center portion } \\
\text { single crystal. }\end{array}$ \\
\hline 26 & $\begin{array}{c}\text { Decrease furnace } \\
\text { temperature and } \\
\text { H.E. temp. }\end{array}$ & $8^{\circ} \mathrm{C}$ & $70^{\circ} \mathrm{C}$ & $\begin{array}{c}13^{\circ} \mathrm{C} / 1 \mathrm{st} \mathrm{hr} \\
130^{\circ} \mathrm{C} / 11.5 \mathrm{hr}\end{array}$ & $8^{\circ} \mathrm{C} / 12.5 \mathrm{hr}$ & $\begin{array}{l}\text { Good seeding. } \\
\text { Center portion } \\
\text { single crystal. }\end{array}$ \\
\hline 27 & $\begin{array}{c}\text { Decrease furnace } \\
\text { temperature and } \\
\text { H.E. temp. }\end{array}$ & $4^{\circ} \mathrm{C}$ & $73^{\circ} \mathrm{C}$ & $\begin{array}{l}4^{\circ} \mathrm{C} / 6 \mathrm{hr} \\
40^{\circ} \mathrm{C} / 8.5 \mathrm{hr}\end{array}$ & $4^{\circ} \mathrm{C} / 14.5 \mathrm{hr}$. & $\begin{array}{l}\text { No seed melt- } \\
\text { back. Poly- } \\
\text { crystalline. }\end{array}$ \\
\hline
\end{tabular}




\begin{tabular}{|c|c|c|c|c|c|c|}
\hline \multirow[b]{2}{*}{ RUN } & \multirow[b]{2}{*}{ PURPOSE } & \multicolumn{2}{|c|}{ SEEDING } & \multicolumn{2}{|c|}{ GROWTH } & \multirow[b]{2}{*}{ REMARKS } \\
\hline & & $\begin{array}{l}\text { FURN. TEMP. } \\
\text { ABOVE M.P. }\end{array}$ & $\begin{array}{l}\text { H.E. TEMP. } \\
\text { BELOW M.P. }\end{array}$ & $\begin{array}{l}\text { RATE OF } \\
\text { H.E. TEMP. } \\
\end{array}$ & $\begin{array}{l}\text { DECREASE } \\
\text { FURN. TEMP. }\end{array}$ & \\
\hline 28 & $\begin{array}{l}\text { Seed and prop- } \\
\text { agate single } \\
\text { crystallinity. }\end{array}$ & $9^{\circ} \mathrm{C}$ & $50^{\circ} \mathrm{C}$ & $\begin{array}{l}10^{\circ} \mathrm{C} / 1 \mathrm{st} \mathrm{hr} . \\
85^{\circ} \mathrm{C} / 13.5 \mathrm{hr} .\end{array}$ & $9^{\circ} \mathrm{C} / 14.5 \mathrm{hr}$ & $\begin{array}{l}\text { Seed melted out. } \\
\text { Columinar grains } \\
1 / 2^{\prime \prime} \emptyset \text { extending } \\
\text { to concave growth } \\
\text { interface at top } \\
\text { of ingot. }\end{array}$ \\
\hline 29 & $\begin{array}{l}\text { Seed and prop- } \\
\text { agate single } \\
\text { crystal to } \\
\text { crucible wall. }\end{array}$ & $6^{\circ} \mathrm{C}$ & $60^{\circ} \mathrm{C}$ & $\begin{array}{l}16^{\circ} \mathrm{C} / 1 \mathrm{st} \mathrm{hr} \\
40^{\circ} \mathrm{C} / 12.5 \mathrm{hr} .\end{array}$ & $9^{\circ} \mathrm{C} / 13.5 \mathrm{hr}$ & $\begin{array}{l}\text { Seed melted out. } \\
\text { Columinar grains } \\
1 / 4 " \emptyset \text { not extend. } \\
\text { ing to convex } \\
\text { growth interface } \\
\text { at top of ingot. }\end{array}$ \\
\hline 30 & $\begin{array}{l}\text { Seed and prop- } \\
\text { agate single } \\
\text { crystal to } \\
\text { crucible wall. }\end{array}$ & $10^{\circ} \mathrm{C}$ & $70^{\circ} \mathrm{C}$ & $\begin{array}{l}10^{\circ} \mathrm{C} / 1 \mathrm{st} \mathrm{hr} . \\
200^{\circ} \mathrm{C} / 14.5 \mathrm{hr} .\end{array}$ & $10^{\circ} \mathrm{C} / 15.5 \mathrm{hr}$ & $\begin{array}{l}\text { Seed melted out. } \\
\text { Columinar grains } \\
1 / 4^{\prime \prime} \emptyset \text {. No } \\
\text { visible growth } \\
\text { interface. }\end{array}$ \\
\hline 31 & $\begin{array}{l}\text { Seed and prop- } \\
\text { agate crystal. } \\
\text { Reduce H.E. temp. } \\
\text { at seeding. }\end{array}$ & $4^{\circ} \mathrm{C}$ & $72^{\circ} \mathrm{C}$ & $\begin{array}{r}6^{\circ} \mathrm{C} / 1 \mathrm{st} \mathrm{hr} . \\
70^{\circ} \mathrm{C} / 9.5 \mathrm{hr} .\end{array}$ & $4^{\circ} \mathrm{C} / 10.5 \mathrm{hr}$. & $\begin{array}{l}\text { Seed melted out. } \\
\text { Columinar grains } \\
\text { with twins } 1 / 2^{\prime \prime} \emptyset \\
\text { extending to } \\
\text { flat interface. }\end{array}$ \\
\hline 32 & $\begin{array}{l}\text { Seed and prop- } \\
\text { agate crystal. }\end{array}$ & $13^{\circ} \mathrm{C}$ & $90^{\circ} \mathrm{C}$ & $\begin{array}{l}10^{\circ} \mathrm{C} / 1 \mathrm{st} \mathrm{hr} . \\
130^{\circ} \mathrm{C} / 14 \mathrm{hr} .\end{array}$ & $13^{\circ} \mathrm{C} / 15 \mathrm{hr}$. & $\begin{array}{l}\text { Seed melted out. } \\
\text { Columinar grains } \\
1 / 4^{\prime \prime} \emptyset \text {. Slightly } \\
\text { convex growth } \\
\text { interface. }\end{array}$ \\
\hline 33 & $\begin{array}{l}\text { Seed and prop- } \\
\text { agate crystal. } \\
\text { Reduce H.E. temp. } \\
\text { at seeding. }\end{array}$ & $6^{\circ} \mathrm{C}$ & $90^{\circ} \mathrm{C}$ & $106^{\circ} \mathrm{C} / 8.75 \mathrm{hr}$ & $6^{\circ} \mathrm{C} / 8.75 \mathrm{hr}$ & $\begin{array}{l}\text { Good seeding and } \\
\text { growth across dia } \\
\text { of crucible. Con } \\
\text { vex growth inter- } \\
\text { face. }\end{array}$ \\
\hline
\end{tabular}


supercooling. Good seed meltback was achieved; an interface between the seed and ingot was not apparent to the naked eye. The boule was cracked in half as usual with the two halves defined by a conchoidal-type (111) fracture surface.

The ingot was very polycrystalline, but the central section did have a large single (111) oriented grain. The geometry of the grain does show that the new growth did propagate from the original (111) seed. One half was sectioned vertically through the seed and etched to show seeding in the central portion. This section was etched to show a dislocation density of $100 / \mathrm{cm}^{2}$ in the seed, $950 / \mathrm{cm}^{2}$ in the seeded area, and $1500 / \mathrm{cm}^{2}$ in the (110) plane of a large grain.

$\underline{\text { Run } 23}$

For Run 23, the melt superheat and the heat exchanger undercooling were decreased to $7^{\circ} \mathrm{C}$ and $80^{\circ} \mathrm{C}$ respectively. This produced good seed meltback to 1.5-inch diameter with no interface apparent to the unaided eye. This boule was cracked in half with many cracks at the crucible wall. The central portion above the seed was single crystalline and polycrystalline in the outer circumferential area. The semi-circular ingot section was defined by a conchoidal fracture surface across the diameter of the ingot. A series 
of X-ray photographs, at various positions on this surface, showed that this surface was inclined relative to the seed at the correct angle required from the relationship between two (111)-type planes. The conchoidal fracture surface is a (111) plane.

The ingot was then sectioned parallel and at right angles to the conchoidal surface, and a third cut was made parallel to the seed. The most noticeable feature of the grain structures in any one. section was the appearance of a well-defined, cone-shaped gräin. A series of $\mathrm{X}$-ray photographs taken on the surface that contained the, cone-shaped grain showed that the base of the cone was a (111) plane; and the inclined section of the cone was the trace of a (111) plane, while the vertical section was the trace of a (110) plane. The top of the cone was again a (111) plane. The adjoining grains in that section do not show the same surface orientation as the cone-shaped grain, but all such grains indicate that they have been. nucleated from surfaces that are near (111) planes. The directions 'within any one grain area are consistent with' the crystallographic planes and directions taken relative to the original" (111) seed.

Thus, it is apparent that single crystal growth has beèn propagated from the (111) seed plane. A triangular cross sectioned areá, defined by a series of (111) planes, 
emanates from the seed. However, due to nucleation from other areas on the crucible bottom, other grains are formed; and, at some point during the growth cycle, these grains interact with the major grain propagating from the seed, and polycrystalline areas are formed.

The dislocation density in the central seeded area was $100 / \mathrm{cm}^{2}$, and $1000 / \mathrm{cm}^{2}$ in the unseeded circumferential area of the ingot.

\section{Run 24}

For Run 24 , the melt was superheated only $3^{\circ} \mathrm{C}$, and the heat exchanger was undercooled $80^{\circ} \mathrm{C}$. For this run, the seed only melted back on the top edge of the seed. This run was characterized by a very definite zone of material that did not melt into the seed. The original seed (thickness of one inch) has a very polycrystalline zone over it. The cross section of the boule, however, did show the characteristic pyramidal regrowth areas defined by the new growing (111) planes.

It was determined by Laue photographs that new growth did occirr on the edges of the seed. However, the radial growth towards the outside edges of the melt was terminated and became polycrystalline.

Resistivity profiles at various points in the cross section show the seed to be n-type material with expected 
resistivities in the range of 2-3 ohm $-\mathrm{cm}$. The new growth (those sections having orientations the same as the seed) were, however, p-type material with higher resistivities in the range of $23-67 \mathrm{ohm}-\mathrm{cm}$.

The fine-grained poly regions had electrical characteristics similar to the seed material. The poly-grained growth over this fine-grained zone was mixed in type; i.e., $\mathrm{n}$ - or $\mathrm{p}-$, or was compensated so that the thermal probe measurements would not give definite indications of either type. The resistivity of the poly-grained zones was of the order of 17-67 ohm-cm.

Run 25

Run 25 was superheated $8^{\circ} \mathrm{C}$, and the heat exchanger was undercooled $78^{\circ} \mathrm{C}$. Good seed meltback to 1.75 inches on the bottom was achieved. The entire center section of the boule was single crystalline (111) growth that grew from the seed. A well-defined interface: was apparent on a (111) cracked surface that extended through the seed. A section of the interfacial area was investigated with a Scanning Electron Microscope. The preliminary investigation revealed the following features:

(a) The interface is extremely shallow and not well, defined as shown in Figure 1, an SEM photo of the interfacial area at $17 \mathrm{X}$ and $900 \mathrm{X}$ magnification. Inclusions are present in the vicinity of the interface as 


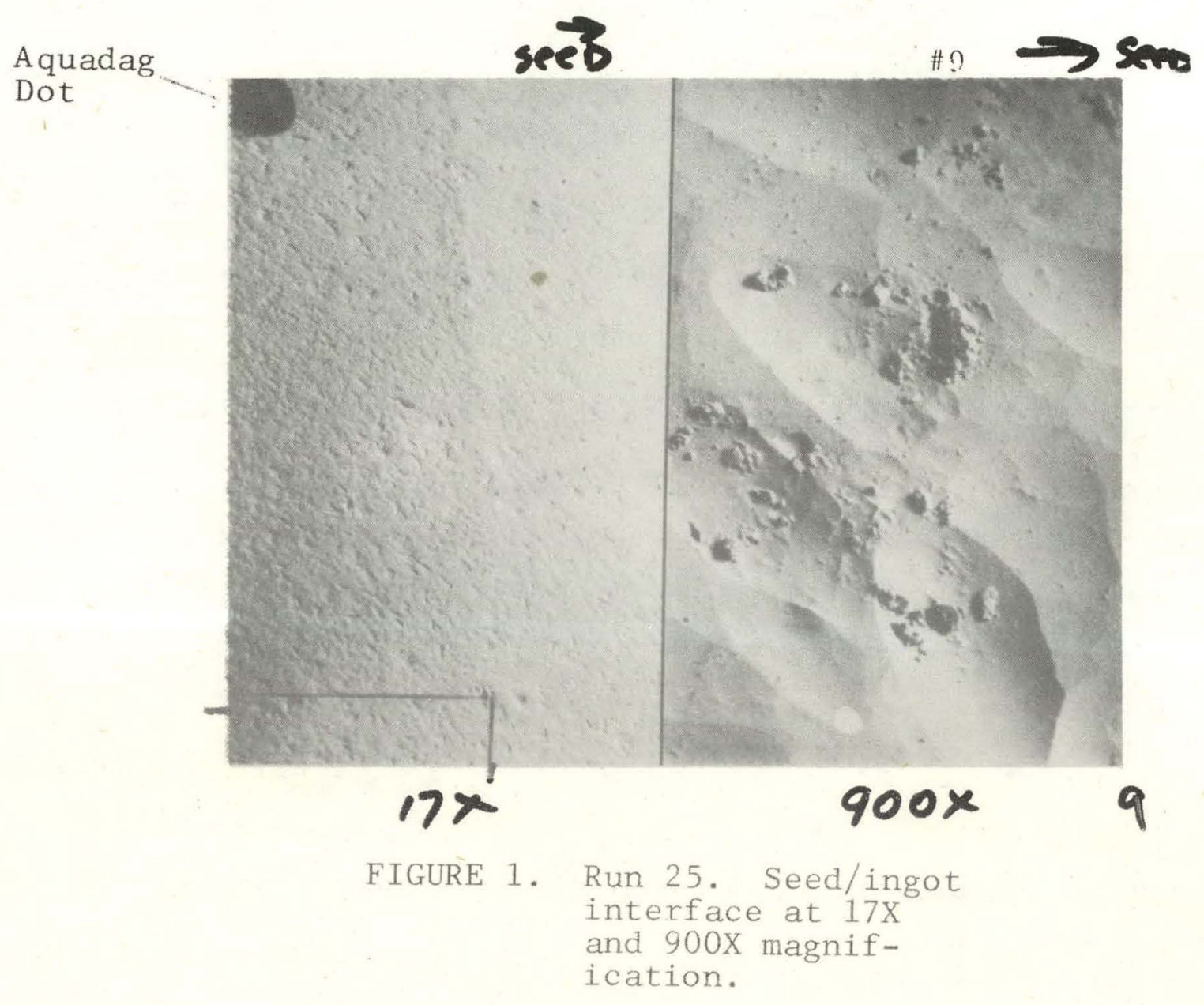


shown in Figure 2, an SEM photo of the interface at 2200X magnification. The inclusions are random]y spaced an'sng the interface and do not appear to have any definite crystalline shape or texture, but may be impurity clusters. Preliminary chemical analysis with the SEM has identifie nickel, iron and manganese as impurities in this area.

(b) Resistivity studies show a pronounced change from $5 \mathrm{ohm}-\mathrm{cm}$-type to approximately $30 \mathrm{ohm}-\mathrm{cm}$-type in traversing from the seed to the ingot. The pronounced wlange in electrical properties suggests that additional SEM investigation should be made using electrically-biased measurements.

Run 26

Run 26 was nearly a repeat of Run 25 with the melt superheated $8^{\circ} \mathrm{C}$, and the heat exchanger undercooled $70^{\circ} \mathrm{C}$, rather than $78^{\circ} \mathrm{C}$. The solidification time, however, was cut in half to twelve hours. Good seeding was accomplished with the entire center section consisting of (111) singlecrystal silicon that grew off the seed. The boule was fractured across the diameter of the solid circular ingot on a (111) plane.

Examination of the relative orientation of the seed and the new growth areas show that the new growth does grow from the seed. All required crystallographic relationships 


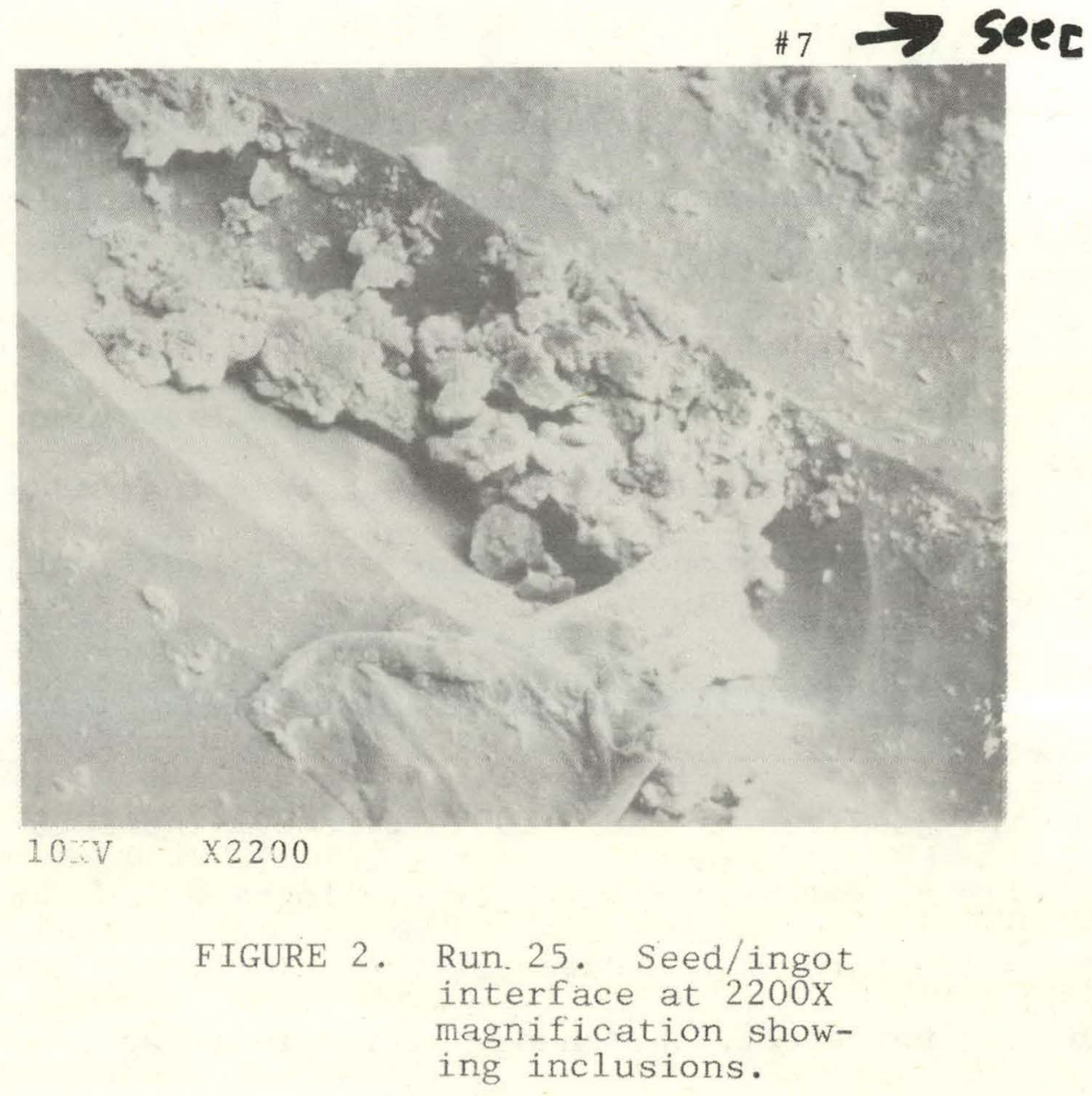


are present. For example, the stereographic projections and Laue patterns show that the (110) or the (111) surfaces noted on the grow material are in the correct geometry when grown from a (111) seed.

In general, the new growth tends to form a pyramidaltype shape due to growth of the (111) planes. However, when the (111) planes that are being grown intersect, the central single-crystal sections are surrounded by a polycrystalline ring of material.

Resistivity profiles were taken on two sections of the boule as shown in Figure 3. All resistivity data was taken with the surface in a ground, rather than an etched, condition. A dotted line is drawn in to indicate the position of the seed interface. There is no significant variation in the crystallographic orientation across the interface. However, there is a very definite and distinct electrical change at the interface. The newgrown material becomes p-type and has a higher resistivity. This suggests that the interface is a $\mathrm{p} / \mathrm{n}$ junction due to the doping of the molten silicon by elements or impurities in the furnace.

Various surfaces were etched using the standard $\mathrm{NF} / \mathrm{HNO}_{3} /$ Acedic Acid etch followed by the Sirt1 $\left(\mathrm{CrO}_{3} / \mathrm{HF}\right)$ decoration etch. Etch-pit counts were taken of the surfaces near the seed and in the new growth areas and were 


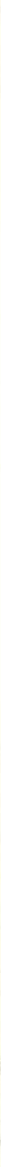

RESISTIVITY PROFILE (At points noted by white dots)

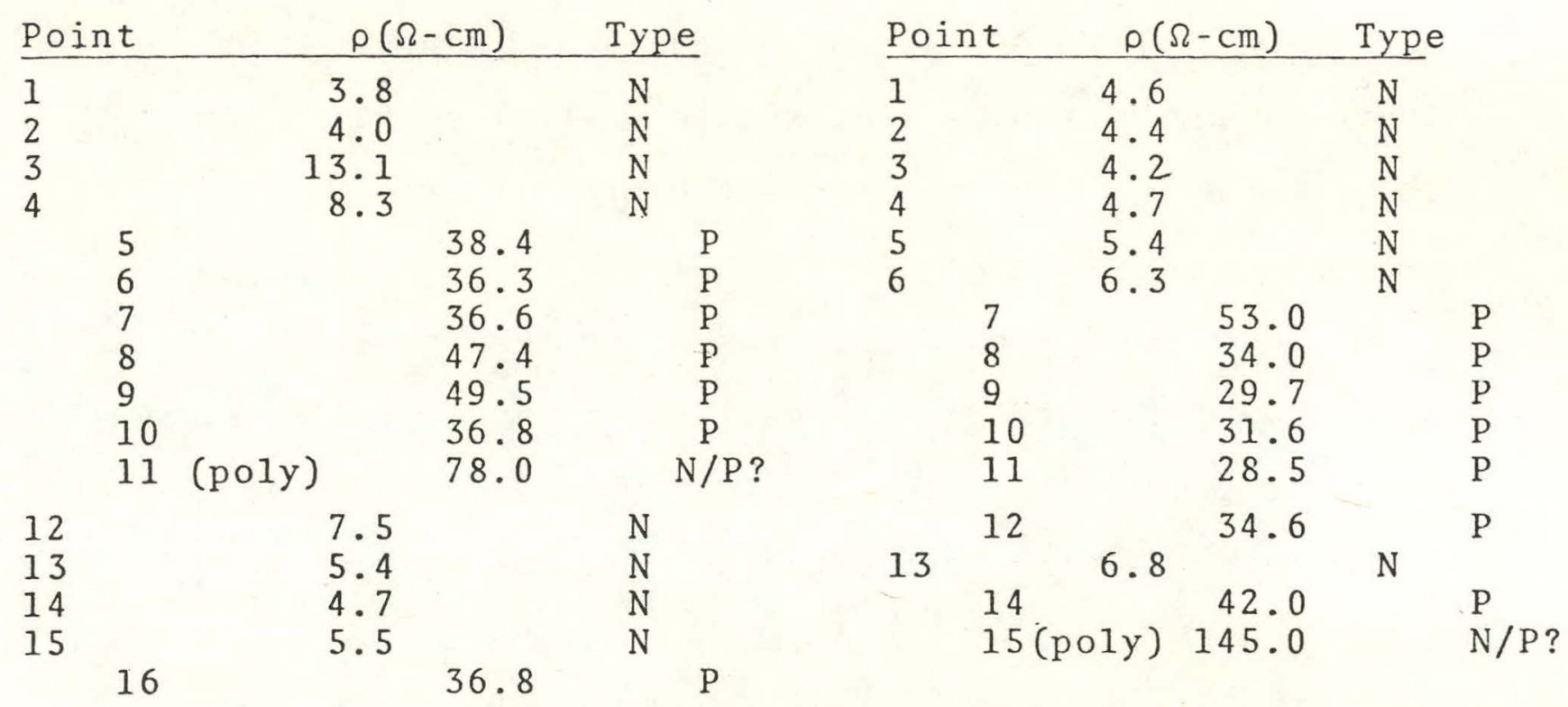

FIGURE 3. Run 26. Resistivity 
approximately $100 / \mathrm{cm}^{2}$.

In all areas, the dislocation counts for the grown material seem to be relatively low, of the order of 100400 counts $/ \mathrm{cm}^{2}$.

\section{Run 27}

Melt superheat temperature for Run 27 was reduced to $4^{\circ} \mathrm{C}$, since decreasing melt superheat below $10^{\circ} \mathrm{C}$ has greatly improved seeding and crystal growth. For this low superheat, the heat-exchanger temperature could only be increased to $1339^{\circ} \mathrm{C}$, or $73^{\circ} \mathrm{C}$ undercooling. No seed meltback was achieved for this ingot because the heat-exchanger temperature could not be increased to a high enough temperature. Material obtained from this run did show many of the typical characteristics seen on other boules. The fracture surfaces were approximately (111) surfaces, and the fractures tended to define the typical triangular (111) sections of new-grown material.

The fracture surfaces present on the "as-grown" boule were ground and etched to reveal the polycrystalline growth over the seed. The interior of the boule was very largegrain material with some directionality of growth from the seed.

The distinguishing feature of this particular run was the appearance of a secondary interface beyond the 
normal planar interface noted on material obtained under more controlled growth.

There was, again, a very definite electric gradient in crossing these interface regions. However, in this particular run, all areas probed show up as p-type materials, even areas in the seed region. This was not seen in other runs.

$\underline{\operatorname{Run} 28}$

For Run 28 the heat exchanger position was raised 1 inch in the heat zone. The seeding and growth conditions were $9^{\circ} \mathrm{C}$ superheat and a $50^{\circ} \mathrm{C}$ heat exchanger undercooling below the melt point. The heat-exchanger temperature was decreased $95^{\circ} \mathrm{C}$ to $1267^{\circ} \mathrm{C}$ over 14 hours. The seed could not be observed on the botton of the ingot or on the cross section through the ingot. However, the major portion of the boule was growth of (111) orientation. Smaller polycrystalline areas were noted near the outside periphery. Resistivities were 20 to $100 \mathrm{ohm}-\mathrm{cm}$ p-type for the most part with some areas of n-type conductivity.

The growth interface near the end of growth was clearly delineated by the breakdown of the solidification front. The concave interface was about one-half inch from the top of the ingot and about one-quarter inch from the top at the outside edge. Growth appears to have advanced in the form of a right eircular cylinder. Breakdown of the solidification 
interiace must have occurréd due to too low a temperature gradient in the liquid, causing constitutional superheating.

\section{Run 29}

Run 29 was solidified starting with $6^{\circ} \mathrm{C}$ superheat and $60^{\circ} \mathrm{C}$ undercooling of the heat exchanger. The heat-exchanger temperature was decreased $56^{\circ} \mathrm{C}$ to $1296^{\circ} \mathrm{C}$ over 13.5 hours. It appears that the seed melted out during the melt-down cycle for no seed or seeding was evident.'

A distinct convex interface was present. It sloped from one-half inch below the top center of the ingot to one inch below the top at the crucible wall. Again, it appears that the liquid gradient was too low causing breakdown of the interface due to constitutional supercooling.

Run 30

For Run 30 the heat-exchanger temperature was reduced to $1342^{\circ} \mathrm{C}, 70^{\circ} \mathrm{C}$ below the M.P., to prevent melt out of the seed. The furnace temperature was stabilized at $10^{\circ} \mathrm{C}$ above the melt point. This was higher than desired due to malfunction of the thermocouple. The seed was melted out for this run. High gradients in the liquid were achieved by the $10^{\circ} \mathrm{C}$ superheat. The $280^{\circ} \mathrm{C}$ undercooling of the heat exchanger produced high solid gradients. This prevented breakdown of the planar interface and, therefore, a growth interface could not be detected. 
Deterioration of the thermocouple during each run has been a generalized problem since its initial use in Run 25. Apparently rhodium diffuses across the couple at $1420^{\circ} \mathrm{C}$ to decrease the compositional difference and reduce the emf output to indicate low temperatures. Even if the thermocouple functioned properly, it would be of limited usefulness in determining the exact melt point since it measures the temperature of the heat zone not the crucible.

\section{Run 31}

For Run 31 a radiation pyrometer was focused on the top of the solid melt stock. A decrease in the emf output should occur at the melt point since the emissivity decreases from 0.475 to 0.3 during melting. In addition, an opticalbrightness pyrometer was focused on the crucible through a hole in the graphite support to pick up the temperature hold during the melting of the solid silicon stock.

Run 31 was superheated $4^{\circ} \mathrm{C}$ and undercooled $72^{\circ} \mathrm{C}$ for seeding. The heat-exchanger temperature was decreased to $1255^{\circ} \mathrm{C}$ over 10.5 hours. Again the seed was melted out.

The ingot consisted of very large twinned grains that extended . to the growth interface which was nearly flat. In the center it was one-quarter inch and the edges one-half inch from the top of the ingot. Twinning of the grains may have happened during the annealing cycle at which time the temperature 
gradient in the solid was decreased by increasing the heatexchanger temperature from $1309^{\circ} \mathrm{C}$ to $1334^{\circ} \mathrm{C}$ in less than 15. minutes. The grains were approximately $25^{\circ}$ from the $\{111\}$ with p-type conductivity of $25 \mathrm{ohm}-\mathrm{cm}$.

\section{Run 32}

-Rún 32 was superheated $13^{\circ} \mathrm{C}$ due to a malfunction of the radiation pyrometer that controlled the furnace temperature. The heat exchanger was undercooled $90^{\circ} \mathrm{C}$ to $1322^{\circ} \mathrm{C}$. It was decreased to $1181^{\circ} \mathrm{C}$ in 15 hours.

The seed-was melted out due to the high furnace superheat.- A slightly concave interface was delineated about one-half inch from the top of the ingot. The ingot consisted of fine columinar grains less than three-sixteenths inch on a side that extended to the growth interface.

Run 33

Run 33 was a (100) seeded boule. The seeding conditions were $6{ }^{\circ} \mathrm{C}$ superheat and $90^{\circ} \mathrm{C}$ heat exchanger undercooling. The furnace and heat-exchanger temperatures were decreased to the melt point and $1216^{\circ} \mathrm{C}$ respectively in eight and three-quarters hours.

The cross section of the boule, Figure 4 (Etched cross section and resistivity profile of boule 33), showed that the hemispherical solidification interface was uniform across the entire boule diameter and had progressed to about a half inch 


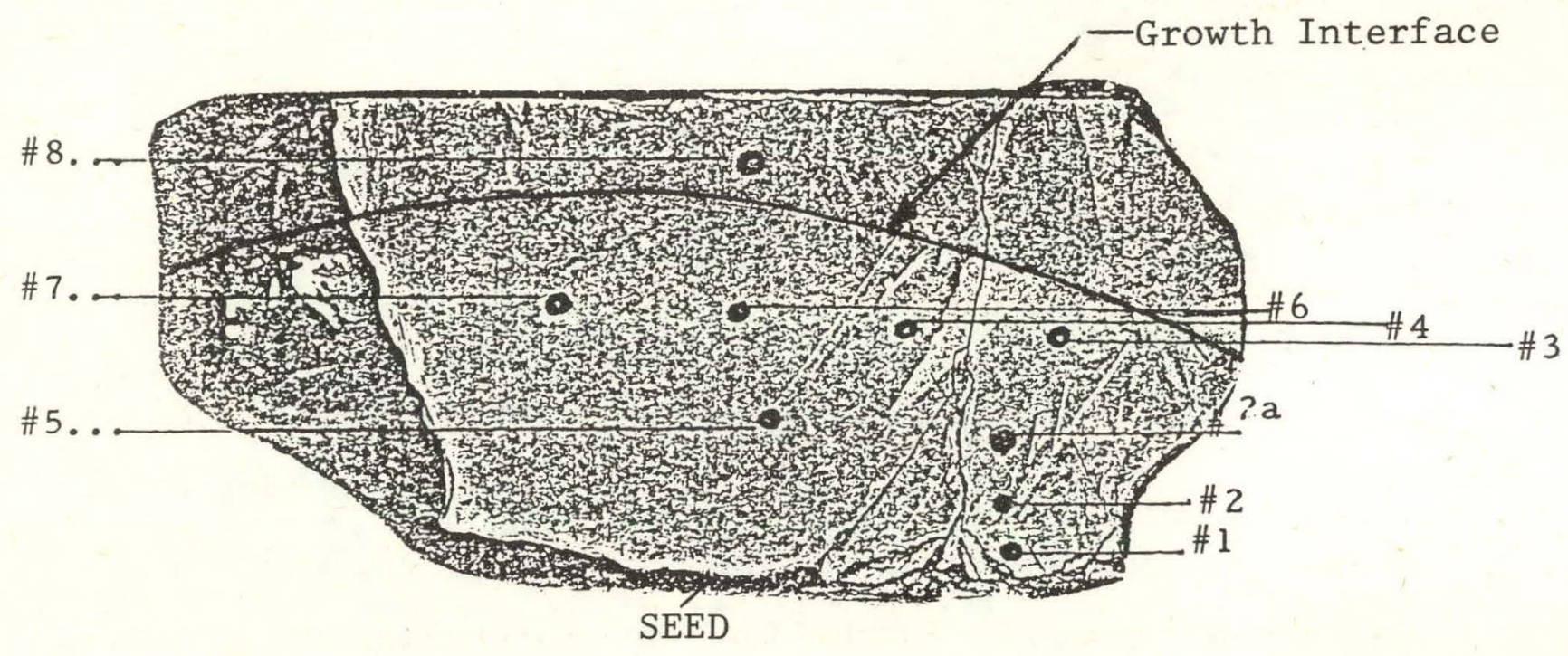

\section{RESISTIVITY PROFILE}

$\begin{array}{lrr}\# 1 & 20.4 & \Omega-\mathrm{cm} \\ \# 2 & 25.8 & \\ \# 2 \mathrm{a} & 26.1 & 25.5 \\ \# 3 & 7.8 \\ & 6.6 \\ \# 4 & 29.4 \\ & 26.0 \\ \# 5 & 29.1 \\ \# 6 & 22.8 \\ & 27.1 \\ \# 7 & 24.1 \\ \# 8 & 22.4 \\ & 32.2 \\ & 29.0\end{array}$

All points show "P"-type conductivity.

FIGURE 4. Etched cross section and resistivity profile of Boule 33 . 
of the top of the melt. No evidence of the seed/new growth interface was observed.

Breakdown of the planar growth front delineates the hemispherical interface. Interface breakdown appears to be due to constitutional cooling resulting from too low a temperature gradient in the liquid. This condition develops when the liquid temperature is decreased too rapid1y in proportion to the heat-exchanger temperature.

The orientation of the seed was verified by a Laue taken of the large surface of the seed and was a (100) plane. An examination of the Laue photographs shows that all areas are of this same orientation, except for a few random grains near the area defined as point 非 2 and point 非 5 .

The electrical conductivity of the materials was p-type, and the resistivity was rather uniform and in the range of $25 \mathrm{ohm}-\mathrm{cm}$. This could suggest that a more constant growth rate was achieved than for previous runs.

Boule 33- was solidified in a $1.5 \mathrm{~mm}$ thick crucible about one half the thickness of standard crucibles in order to prevent cracking. Cracking was minimized as is apparent in Figure 4. A leak developed in the crucible during solidification making it apparent that a thinner walled crucible cannot be 
used to prevent cracking during cool down. It is not strong enough to contain the molten silicon during solidification but is too strong to-break under compressive loading during the cool-down cycle when it is tenaciously bonded to the silicon ingot.

\section{GENERAL DISCUSSION}

Silicon Seeding and Growth

All runs up to Run 23 were superheated in excess of $10^{\circ} \mathrm{C}$. A distinct interface developed between the seed and the new growth because the seed had to be maintained too cool to prevent it from melting out.

The high temperature gradients that resulted from superheats in excess of $10^{\circ} \mathrm{C}$ did not promote single crystallinity, for areas that. nucleated off the seed broke down into large columinar grains. However, good directional solidification was achieved at high temperature gradients. Runs after Run 22 were seeded at temperatures near or below $10^{\circ} \mathrm{C}$. For superheat temperatures below $7^{\circ} \mathrm{C}$ (Runs 24 and 27), the heatexchanger temperature could not be increased sufficiently to achieve seed melt back for nucleation of the seed. The heat exchanger was raised one inch higher in the heat zone after Run 27 to achieve higher heat-exchanger temperature at low superheat temperatures.

Seed melt out occurred for Runs 28 and 29 due to exces- 
sive heat-exchanger temperature during seeding. By ràising the heat exchanger, the temperature in the center of the furnace at the heat exchanger level was higher for equal superheat temperatures. The heat-exchanger temperature had to be decreased from the previous temperatures to previent seed melt out. This effect was stronger than expected since, as the heat-exchanger temperature was lowered, the thermal conductivity of the quartz was also decreased. Due to this effect, the seed temperature was not lowered as much as the heat-exchanger temperature. Examples of this are Runs 27 and 31. In both cases, the furnace temperature was superheated $4^{\circ} \mathrm{C}$, and the heat exchanger was undercooled $72^{\circ} \mathrm{C}$. For Run 27 (lower heat exchanger position), there was no seed melt back; and for Run 31 (higher heat exchanger position), the seed melted out. Although the superheat temperatures and undercooling are the same, the temperature in the center of the zone was higher and required a lower heat-exchanger temperature. The uniform temperature across the diameter of the furnace was favorable for single crystal growth as illustrated by Run 33. The uniform temperature across the diameter of the crucible allows not only for good seeding, but also for good growth. This is illustrated in Figure 4 for Run 33 where crystal growth has extended across the entire diameter of the crucible.

Runs $28,29,31,32$, and 33 exhibited a distinct growth 
interface due to breakdown of the planar growth interface. The interface breakdown probably is due to constitutional supercooling caused by too low a temperature gradient in the liquid. This condition results when the crystal growth is driven by reducing the furnace temperature too rapidly and not increasing the solid gradient rapidly enough. Crystal growth is controlled by controlling the rate of furnace and heat exchanger temperature decreases. To optimize growth, the furnace temperature must be decreased in the proper proportion to heat-exchanger temperature decrease.

\section{Ingot Cracking}

All ingots produced by the Heat Exchanger Method have cracked regardless of the annealing or cool-down cycle.

The cracking occurs during the cool-down cycle. The silicon forms a strong bond with the quartz. Silicon's expansion coefficient is about 5 times greater than the quartz causing it to go into tension and the quartz to go into compression during the cool-down cycle. Ingots 32 and 33 were viewed with a fiber-optic light source during the cool-down cycle to determine the temperature at which the ingots cracked. Both ingots were cooled at less than $1^{\circ} \mathrm{C} / \mathrm{min}$. and cracked at about $650^{\circ} \mathrm{C}$. This confirmed that the crystals cracked during the cool-down cycle, not during solidification. Hino and Strauss ${ }^{1}$ attributed cracking of silicon ingots... 
solidified in fused silica crucibles to the differential contraction of silicon and fused silica. The silicon forms a bond that adheres tenaciously to the crucible. They were able to cause the crucible to fail in compression before the silicon cracked by reducing the wall thickness to less than $0.5 \mathrm{~mm}$. They state "With such thin-walled fused quartz crucibles, consistently uniform success is secured in producing sound ingots $30 \mathrm{~mm}$ in diameter." ${ }^{1}$

For Run 33, a thin-walled $1.5 \mathrm{~mm}$ crucible was used. This minimized cracking in Boule 33 as is apparent from Figure 4. A leak developed in the crucible during solidification making it apparent that a thinner-walled crucible could not be used to prevent cracking during the cool-down cycle of the Heat Exchanger Method. It is not strong enough to contain the molten silicon during solidification but is too strong to break under compressive loading during the cool-down cycle when it is tenaciously bonded to the silicon ingot.

It appeared that the cracking was independent of diameter since the cracking Hino and H. E. Strauss ${ }^{1}$ described for their $30 \mathrm{~mm}$ diameter ingots was the same as for our $150 \mathrm{~mm}$ ingot. This was confirmed by reviewing Run 9 where there was only partial melting and partial melt contact of the silicon melt stock with the crucible wall. Cracking occurred for both the silicon and the crucible even where 
the contact area between the silicon melt stock and the crucible was less than $1 \mathrm{~cm}$ diameter. This observation makes it clear that the localized stress between the silicon and silica is causing cracking of the silicon ingots.

To prevent the cracking, the bond strength between the silicon and the crucible must be reduced. One method for achieving this is to coat the inside of the fused silica crucible with a sintered silica coating. The strength of the coating and the bond it makes with the crucible can be controlled by its thickness, density and polymorphic form.

\section{Impurity Pickup}

It has been noted that for most runs the seed was approximately $5 \mathrm{ohm}-\mathrm{cm}$ n-type, probably due to phosphorous; and the ingots were approximately $30 \mathrm{ohm}-\mathrm{cm} \mathrm{p}$-type due to an unknown impurity.

During the solidification the last liquid to freeze-termed the "rat-tail" section--was darker in color. Specimens from the interior of the silicon ingot grown as Run 21 and specimens from the "rat-tail" section of the same run were selected for this analysis. Chemical analysis of this section was made in order to determine if any impurities might be concentrated in such sections.

Some initial measurements were made using the electron 
microprobe to determine if any gross segregations might have occurred. It was expected that no changes or differences would be observed using this technique since the method does require impurities in the range of a few percent. However, electron microprobe traces of the two specimens taken under identical conditions show a considerable amount of iron, estimated to be the order of a few percent, to be present in the "rat-tail" section. No traces were detected in the specimen from the interior of the crystal.

As another check on the type of impurities that might be present, the conductivity type of the initial seed material, the interior of the silicon ingot, and the "rattail" section were measured. It was found that the initial seed. was n-type as expected. The interior sections showed both $\mathrm{n}$ - and p-type regions, while the "rat-tail" section and areas just below the section were very strongly p-type material.

In order to determine possible sources of the iron impurity that was detected in the "rat-tail" section of the solidified ingots of silicon, various components of the furnace section were examined using the electron microprobe. The following observations were made:

(a) A sample of unused graphite taken from the retainer did contain a significant amount (possibly $1-2 \%$ ) 
iron, with some indication of calcium, potassium and traces of sülfur and possibly chlorine.

(b) "A sample of graphite used in the furnace showed considerable silicon, undoubtedly picked up dưring the growth process. The iron and potassium leviels were very much lower than from the unused graphite.' It appears that the iron "was drawn out of the graphite during the heat and growth cy̆cles."

Thì shows that it is especially important to use high-purity graphite in the heat zone. The 0.1 torr vacuum will draw all impurities out of the graphite whose vapor pressure is greater than 0.1 torr at $1425^{\circ} \mathrm{C}$.

\section{Temperature Control}

Determination of the melt point by focusing a pyrometer on top of the melt was not successful for Runs 31 and 32 since a film of different emissivity formed on the top of the melt. At melt down, the emf output actually increased rather than decreased, as would be expected due to the decrease in emissivity. The density of the film changed during the runs; this also affects the emissivity and made it impossible to use this method as a slandard.

Focusing of the optical-brightness pyrometer on the wall of the crucible was not successful in observing a hold in the temperature during the melt down. The bright- 
ness pyrometer cannot be focused sufficiently on one spot on the wall of the crucible. The brightness appears to be affected by diffuse radiation.

It is important to determine the precise melt-point temperature so that the exact superheat temperature can be achieved repeatedly. This was accomplished for all'runs preceding Run 33 by focusing a radiation pyrometer on the wail of the crucible. A liquid, temperature hold occurs at the melt point until melting is complete. 


\section{SILICON CRYSTAL SLICING}

\section{$\underline{\text { Summary }}$}

\section{Slicing Testing}

During the reporting period, slicing testing ${ }^{1}$ was continued using wire blades, ${ }^{2}$ coordinated motion, ${ }^{3}$ and the modified multi-blade wafering machine, ${ }^{4}$ Figures 5,6 , and 7.

Data were collected for the ultimate purpose of establishing the limits of the process. However, testing to date has necessarily been focused on defining the significant basic relationships.

Representative samples of data from Runs 1, 2, 2B, 3, $4,5,5 \mathrm{~B}$, and 6 are discussed below, to the extent that the data have been reduced to reportable form at the present time.

Detailed results and conclusions will be presented in succeeding reports as analysis continues.

1. Testing, pp. $31,32,33$, ref. 2 .

2. Wire blades, p. 26, ref. 2 .

3. Coordinated motion, pp. 29, 30, 31, ref. 2 .

4. Modifications to the Varian 686 multiblade wafering machine, p. 23, ref. 2 . 


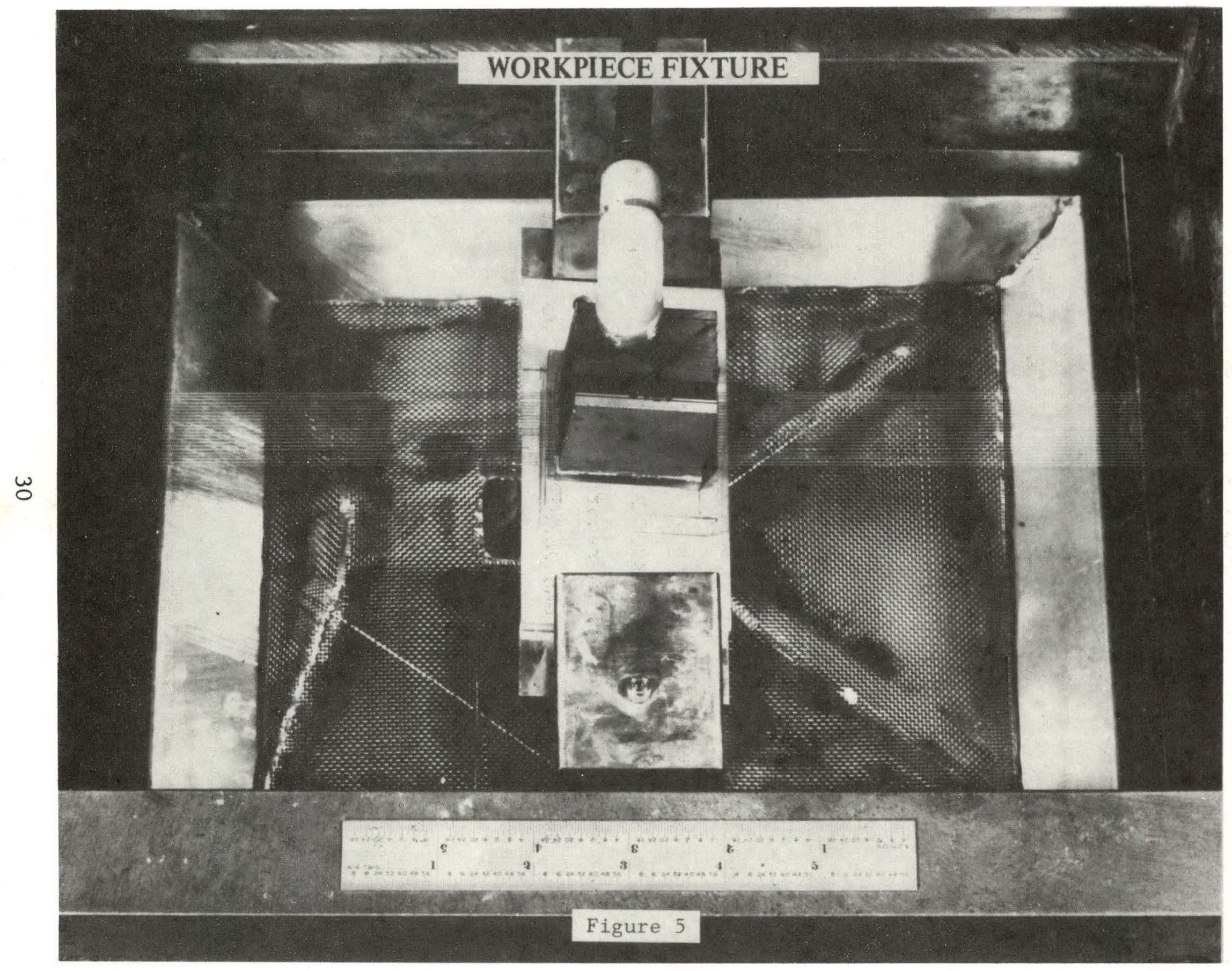




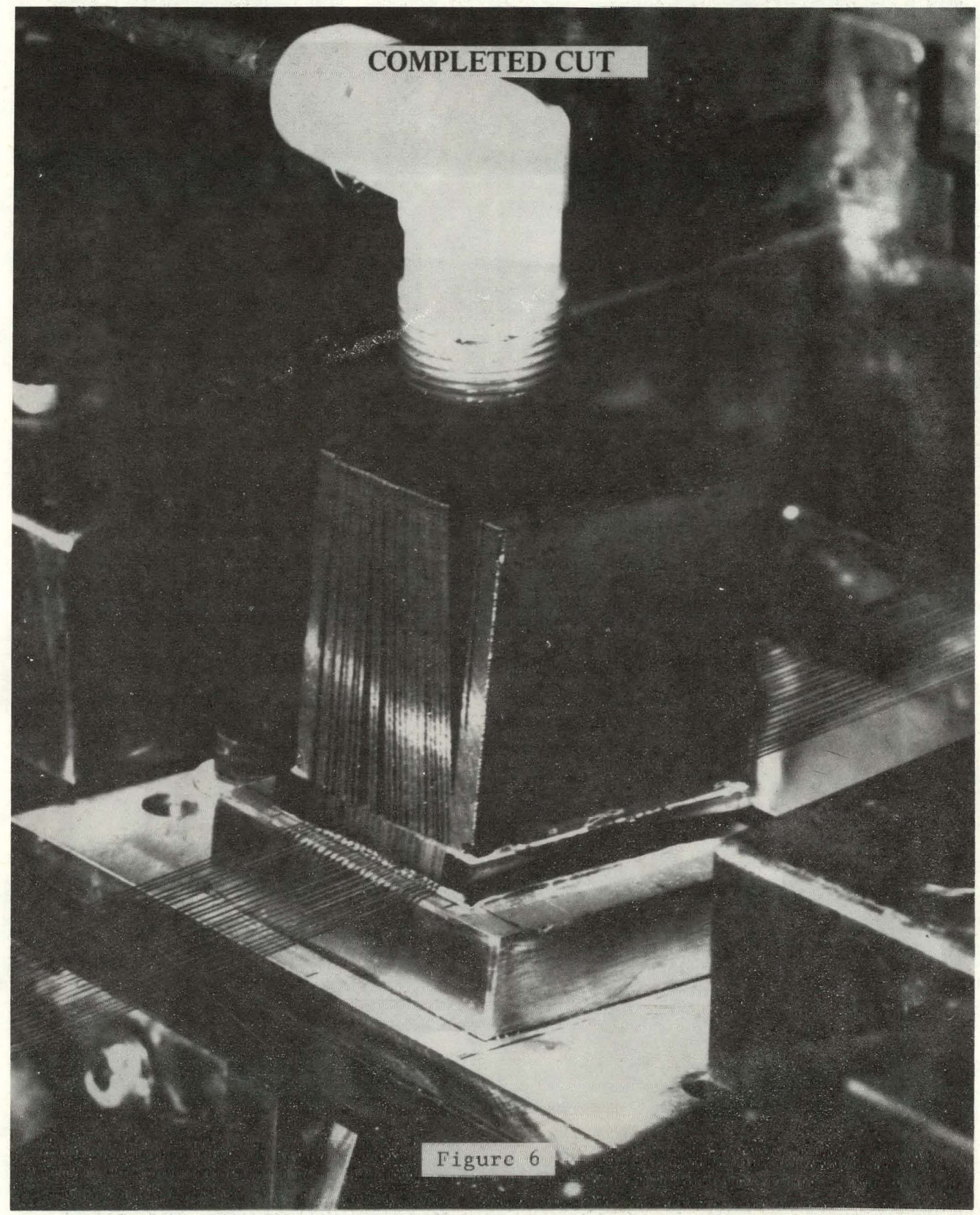




\section{CUT PROFILE}

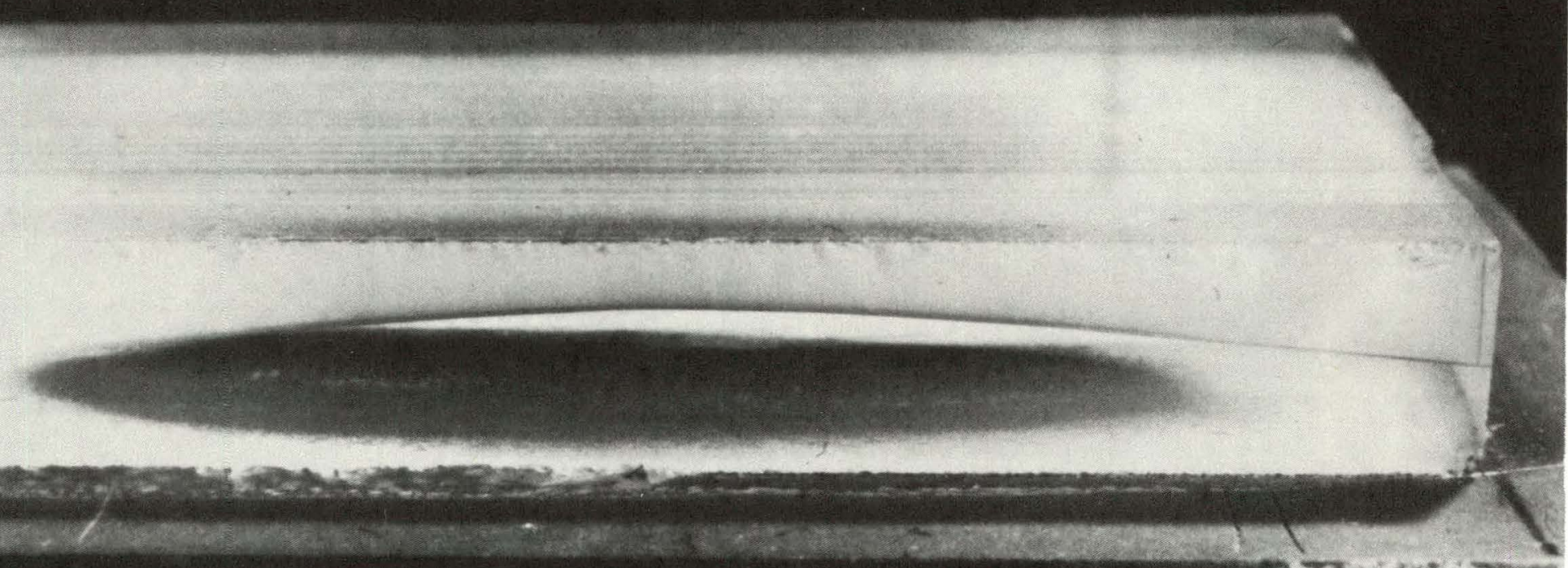


Selection of the most useful parameters for presentation of performance comparisons, for slicing with coordinated motion and wire blades, will logically result from further analysis of the process and interpretation of test results. At the present time a total of approximately 10 dependent and 30 independent variables have been identified, each requiring consideration of some extent.

The 12 variables of principal interest were described on pages 28 and 29 of reference 2 .

The three dependent variables of most immediate interest at present, as components in the total economic equation of the process, are the following.

TABLE 2

VARIABLES

\begin{tabular}{|c|c|c|}
\hline SYMBOL & UNITS & DEFINITION \\
\hline & $\begin{array}{l}\mathrm{mils} / \mathrm{min} \\
\text { and } \\
\mu \text { in/stroke }\end{array}$ & Cutting rate \\
\hline & $\begin{array}{l}\mathrm{mils} / \mathrm{min}^{2} \\
\quad \text { and } \\
\mu \text { in/stroke }\end{array}$ & $\begin{array}{l}\text { Degradation } \\
\text { rate }\end{array}$ \\
\hline$A X$ & inches & Abrasive life \\
\hline
\end{tabular}




\section{Blade Characterization}

Blade characterization testing was begun when inferior cutting rates were experienced using impregnated wire from different lots of the same material and when unexplained yielding of the wire occurred.

Preliminary results from strength, hardness, and composition testing, together with surface microphotography, established that diamond concentration was much lower for the second lot of impregnated wire than for the first.

Gross differences in wire strength and composition also existed between the different lots of impregnated wire. Improved manufacturing controls and routine in-house blade characterization are expected to eliminate excessive variations in blade properties.

\section{Machine Calibration}

Machine calibration testing and analysis was performed for enabling better machine control and data interpretation.

Determinations are now possible with greater accuracy of feed force and blade tension from test data.

\section{Data Reduction}

A data reduction program was begun for the purpose of filling the particular requirements of the program. 
This involves the efficient use of test data in order to minimize the total number of tests required and to minimize the lengths of individual tests.

\section{Slicing Procedure}

As slicing data have accumulated for coordinatedmotion slicing with diamond-impregnated wires, and as cause and effect relationships have developed, means for improving the process have become apparent.

Anticipated changes in procedure are discussed briefly below.

Results and Discussion

Detailed results and conclusions will be presented in succeeding reports as additional data are reduced to reportable form. Following are current preliminary findings.

\section{Slicing Testing}

Testing prior to Run 2B involved many changes of machine settings, for the purpose of obtaining gross machine operating characteristics. Data from all testing to the present are in various stages of reduction and analysis. Additional portions of those data will be presented, as they become available. 
Of immediate importance is the establishment of the key relationships between the 40 presently-identified variables.

\section{Discussion - Run 2B}

The data reported in Figures 8 through 13 for Run 2B are data for a cut which was made using the smallest number of changes in machine settings at the time. The cut in this case was through approximately the last half of a $1.5 \times 1.5 \mathrm{in.} \mathrm{silicon} \mathrm{workpiece,} \mathrm{the} \mathrm{first} \mathrm{half} \mathrm{of} \mathrm{the}$ cut having been made with a different set of blades and having involved several different machine settings.

Run 2B was performed with 230.008 in. D wires impregnated with $45 \mu$ diamonds.

Figure 8 is a plot of half of the values of $\dot{Y}$ available from the data, if all values were to be computed in the same way. For the purpose of preliminary examination, values of cutting rate, $\dot{Y}$, in mils/min were computed for every other dial reading of depth of cut, $Y$, in mils on the original data sheet. A simple local slope was calculated using dial readings at the beginning and end points of each ten minute interval, and the value of $\dot{Y}$ was plotted on Figure 8 in the center of each interval. 


\section{$R \cup N \perp B$}

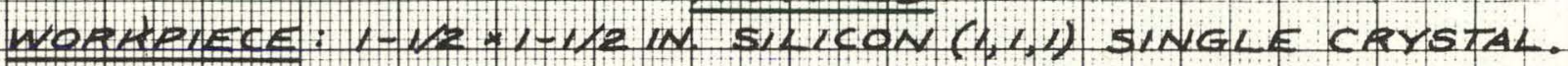
BLADES: 0.006 N D WRE WTH F5 LL MPREGNATED DIAMONDS.

\begin{tabular}{|c|c|c|c|c|c|c|c|c|c|c|c|c|c|}
\hline $\begin{array}{l}\text { I. } \\
\text { No. }\end{array}$ & \multicolumn{2}{|c|}{45} & \multicolumn{2}{|c|}{$\Delta \sqrt{E}$} & \multicolumn{2}{|c|}{ REMARAS } & $\frac{I D}{N O}$ & \multicolumn{2}{|c|}{45} & \multicolumn{2}{|c|}{$\Delta F$} & \multicolumn{2}{|c|}{ RENARKS } \\
\hline & \multirow{2}{*}{\multicolumn{2}{|c|}{$\frac{\text { STROKe }}{\min }$}} & \multirow{2}{*}{\multicolumn{2}{|c|}{$\frac{\angle B E}{B L E}$}} & & & & \multirow{2}{*}{\multicolumn{2}{|c|}{$\frac{\text { STROKE }}{\text { MNN }}$}} & \multicolumn{2}{|c|}{$\angle E F$} & & \\
\hline & & & & & & & & & & $E L$ & DDE & & \\
\hline & FN & 70 & $7 x$ & 70 & 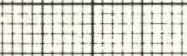 & & $H$ & $\overline{F M}$ & 70 & $F M$ & 70 & & \\
\hline 1 & 0 & 100 & 0 & .1 .05 & & 11 & 13 & HH: & it: & 149 & .213 & & \\
\hline 2 & & & .05 & .075 & & & 14 & 180 & 0 & $2 / 3$ & 0 & & \\
\hline 3 & 100 & 150 & H, & \#\# & He & & 15 & 0 & 15 & 0 & $4+5$ & & \\
\hline 4 & \#\# & $\#$ & .075 & $1+9$ & & & 16 & 150 & 180 & +5 & & & \\
\hline 6 & 150 & 0 & 14 & 0 & $F$ & 甚 & 17 & it & H: & 179 & .213 & & \\
\hline 6 & 0 & 150 & $\phi$ & .000 & $H=$ & $t i t$ & 18 & 180 & 0 & 213 & $\phi$ & & \\
\hline 7 & & t7 & .015 & 149 & $t$ & & 19 & 0 & 150 & 0 & .075 & & \\
\hline 8 & & & .159 & 149 & AONYST & $F$ & 20 & & & 0,5 & .149 & & \\
\hline 9 & 150 & 100 & HAH & & & 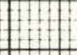 & $2 t$ & & & .1As & .213 & & \\
\hline 10 & 180 & 0 & .149 & 9 & $C: B / F \mid<7$ & $E \in R$ & 22 & 150 & 180 & & & & \\
\hline 11 & 0 & 100 & $\phi$ & 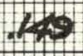 & & & 23 & & & .204 & $.2 / 3$ & ADTUST & A \\
\hline 12 & 130 & 180 & 4 & $\begin{array}{r}7+11 \\
\end{array}$ & A日, & & 24 & 180 & 0 & $2 / 3$ & 0 & ENAOK & wht \\
\hline
\end{tabular}

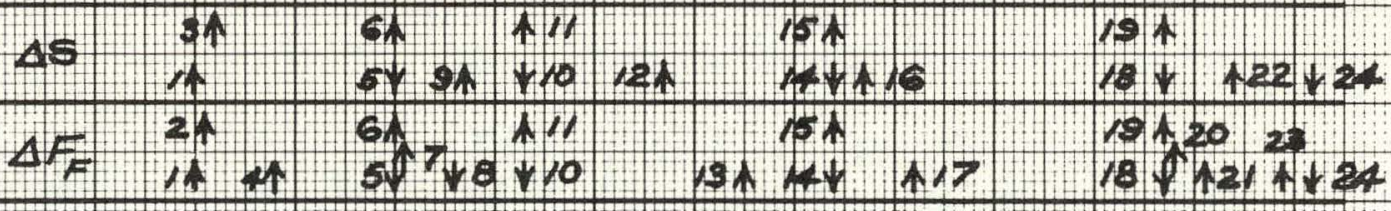

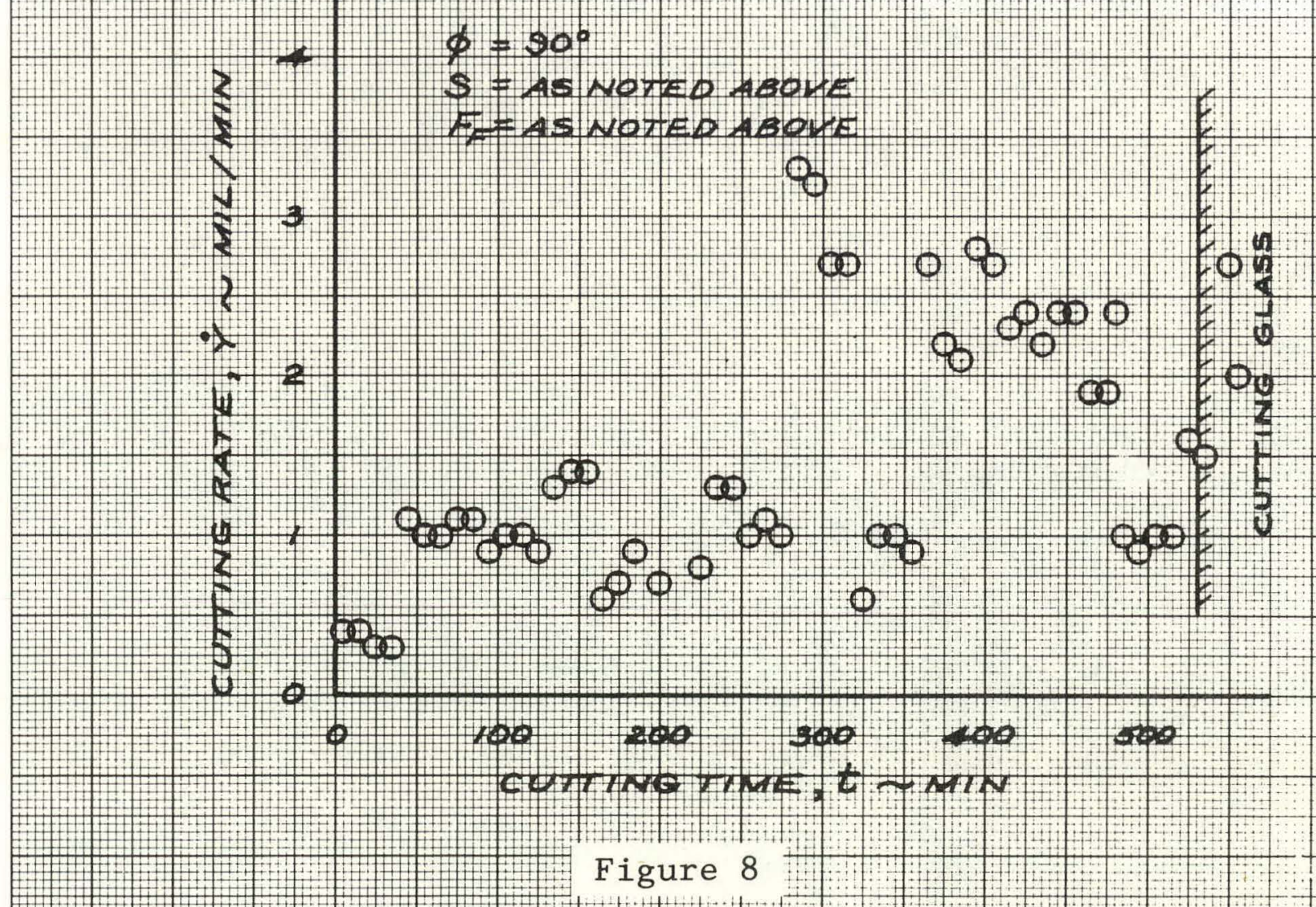




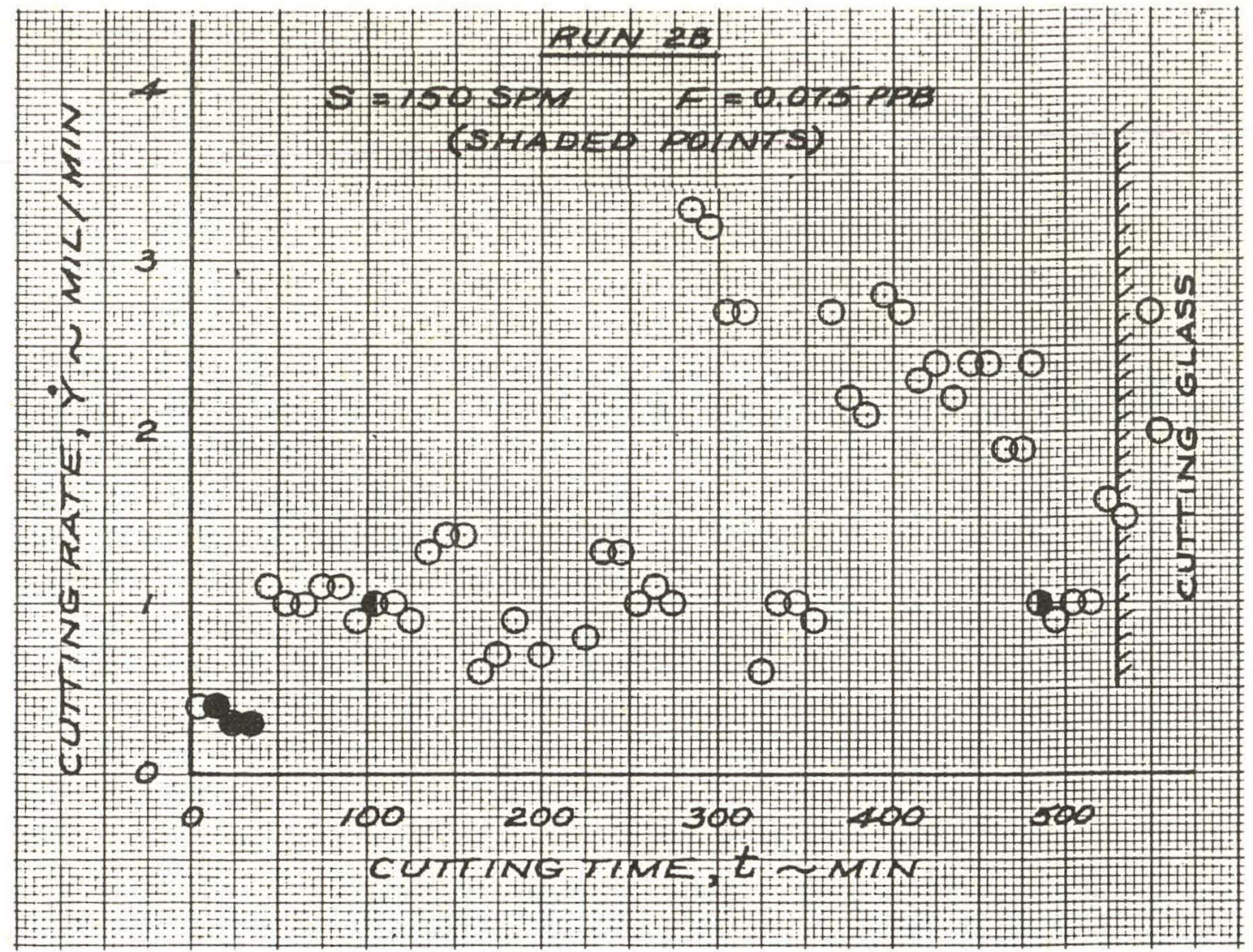

FIGURE 9 .

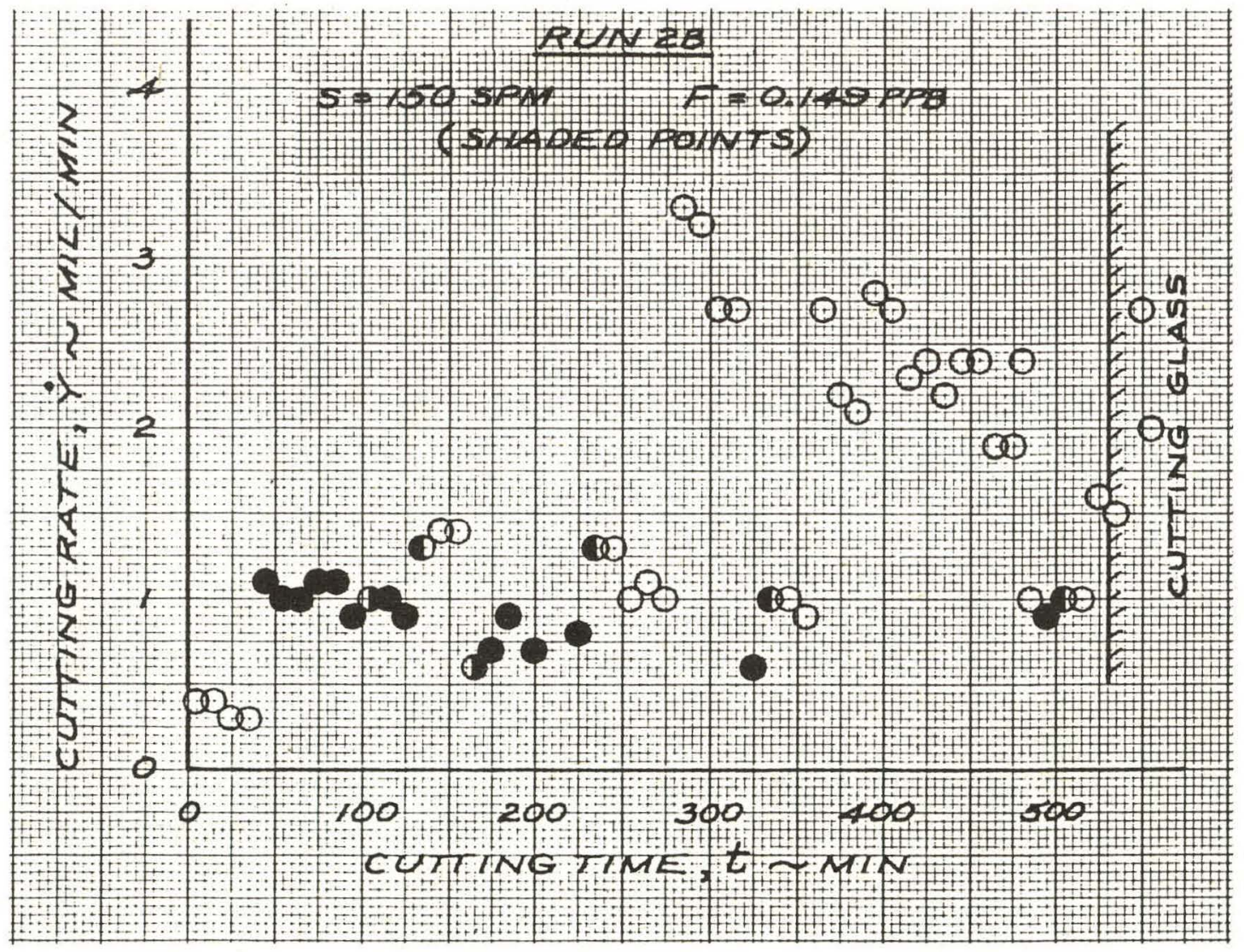

FIGURE 10 . 


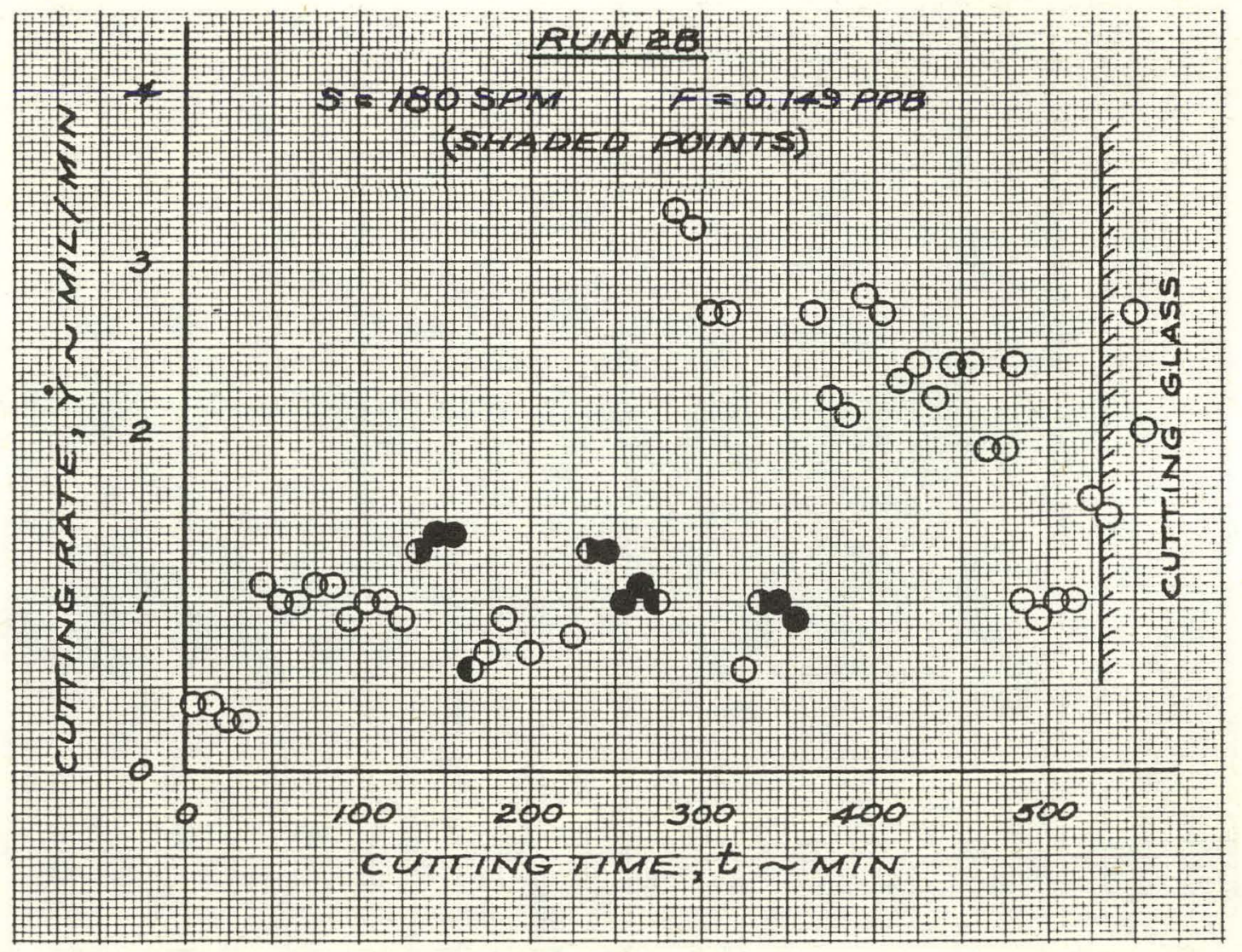

FIGURE 11 .

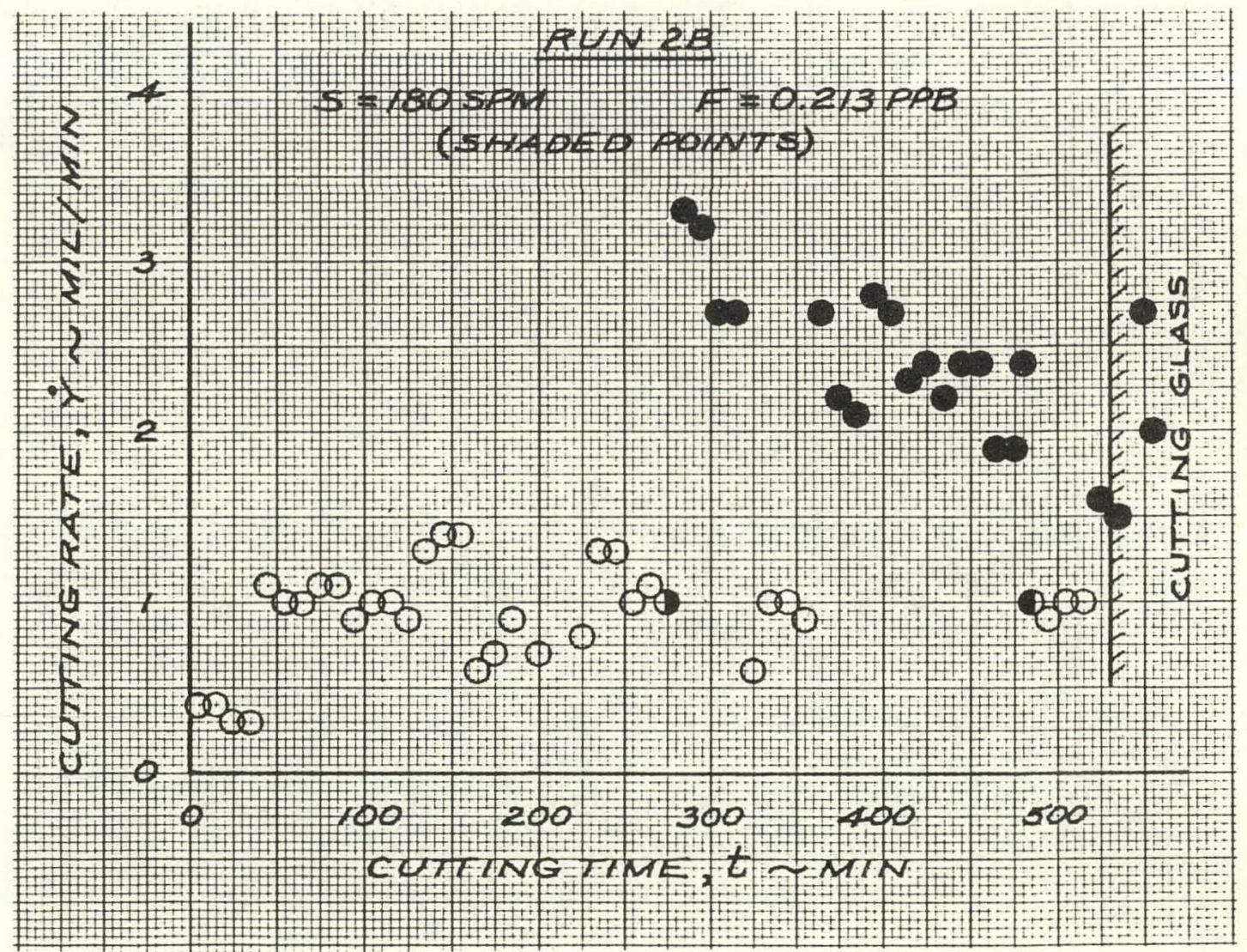

FIGURE 12. 


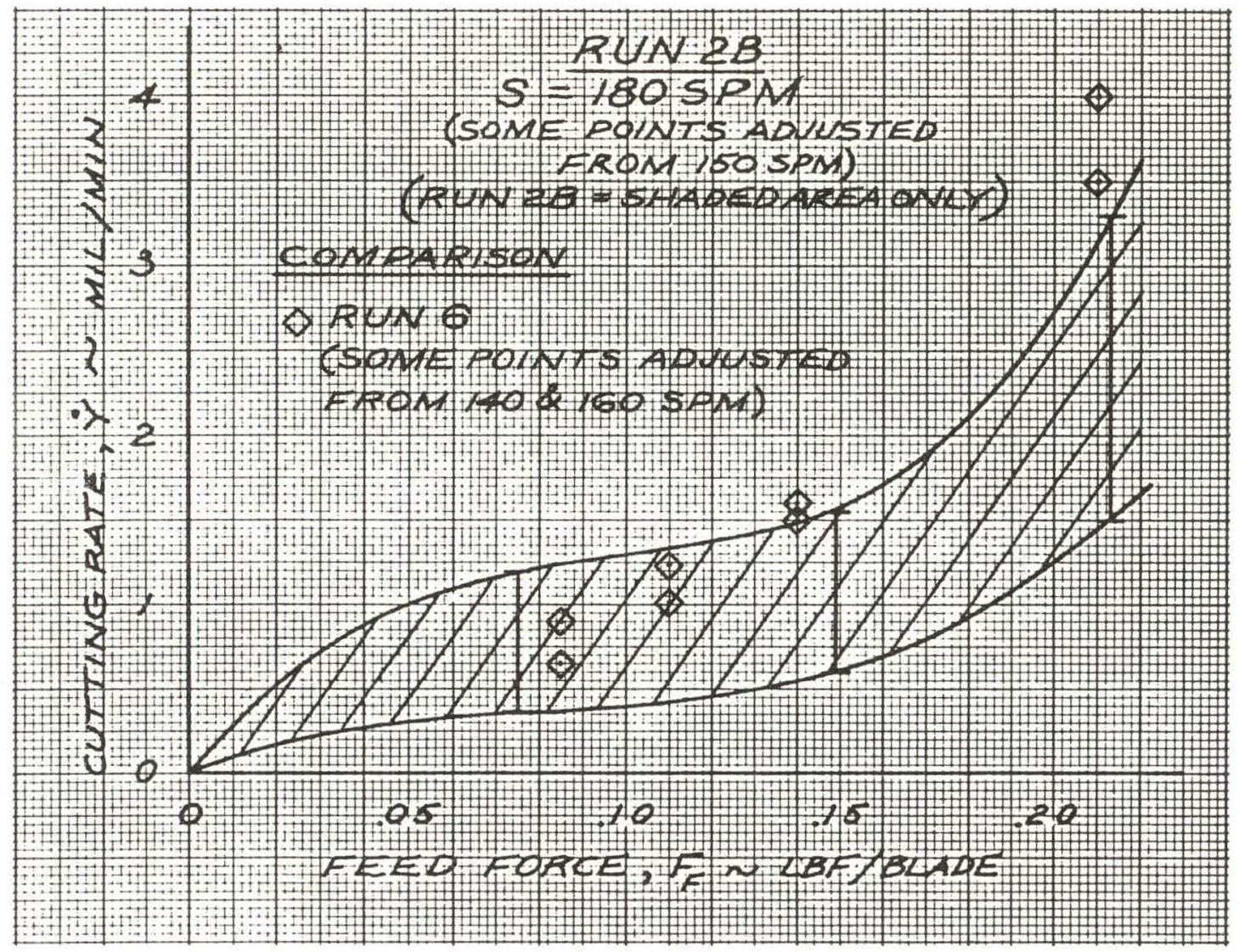

FIGURE 13. 
Final analysis will involve more data and additional steps of data reduction and interpretation.

Figures 9 through 12 are reprints of the points plotted in Figure 8, with points for four different conditions shaded separately.

The shaded area in Figure 13 is a cross plot of values from Figures 9 through 12, attempting to show the general trend of cutting rate with feed force, but not the limits of the process, as will be discussed below.

The superimposed points in Figure 13 from Run 6 will be discussed later in this report.

The maximum values of cutting rate, $\dot{Y}$, in Figure 13, as well as the spread of values of $\dot{Y}$ shown for each value of feed force, $F_{F}$, come directly from the maximum and minimum values in Figures 9 through 12, with values from Figures 9 and 10 adjusted by the speed ratio of $180 / 150$. The maximum values of $\dot{Y}$ and the ranges of values of $\dot{Y}$ in Figures 9 through 12 are results of a number of phenomena. These need further description and isolation from each other before causes and effects and the limits of the process will be established.

In Figure 13 the range of values for cutting rate, $\dot{Y}$, for coordinated-motion slicing, with present commercially available diamond-impregnated wire blades, and using a 
phase angle, $\phi$, of $90^{\circ}$, on a $1.5 \times 1.5$ in. silicon workpiece, would indicate that cutting rates of from 1 to 4 $\mathrm{mil} / \mathrm{min}$ should be possible in the range of feed force, $\mathrm{F}_{\mathrm{F}}$, from 0.05 to $0.251 \mathrm{bf} / \mathrm{blade}$.

With regard to degradation, from Figures 9 through 12, and especially Figure 12, one can picture a downward sloping trend suggesting degradation of cutting rate which increases with feed force.

Regardless of the meaning of the particular values shown, a reasonable likelihood would seem to exist that some optimum feed force or program of feed force with time will be found which gives the most economical relationship between cutting rate, $\dot{Y}$, degradation rate, $\ddot{Y}$, and hence abrasive life, $\Delta Y_{\text {MAX }}$.

For the condition where degradation rate, $\ddot{Y}$, is approximated as a constant, then abrasive life, $\Delta Y_{\text {MAX }}$, can be expressed as

$$
\Delta Y_{\text {MAX }}=\frac{1}{2} \frac{Y_{i}^{2}}{\ddot{Y} \operatorname{CONST}}
$$

where $\dot{Y}_{i} \equiv$ the cutting rate of the new blade.

From the data shown in Figures 10, 11, and 12, and using the above relationship, one can obtain the abrasive life estimates shown in Table 3. 
TABLE 3

ABRASIVE LIFE

\begin{tabular}{|c|c|c|c|c|}
\hline$S$ & $\mathrm{~F}_{\mathrm{F}}$ & $\dot{Y}_{i}$ & $\ddot{Y}_{\text {CONST }}$ & $\Delta Y_{\operatorname{MAX}}$ \\
\hline$\frac{\text { stroke }}{\text { min }}$ & $\frac{1 b f}{b \operatorname{lade}}$ & $\frac{\operatorname{mil}}{\min }$ & $\frac{\operatorname{mil}}{\min } 2$ & in \\
\hline 150 & 0.15 & 1.1 & $\begin{array}{l}0.42 \\
\times 10^{-3}\end{array}$ & 1.5 \\
\hline 180 & 0.15 & 1.4 & $x+10^{2}-3$ & 0.40 \\
\hline 180 & 0.21 & 3.3 & $x{ }^{7} 10^{-3}$ & 0.77 \\
\hline
\end{tabular}

The abrasive life estimates in Table 3 for the present diamond-impregnated wire were encouraging.

The causes of degradation in cutting rate as discussed later in this report are being examined. SEM photos of used and unused wire, Figures 14 through 18, showed a lower and less uniform concentration of diamonds in the used areas, but without conclusive evidence of diamond pull out. This suggested that some diamonds had been imbedded in shallow cavities and were loosened during initial cutting. 


\section{Discussion - Runs 1, 2, 2B, 3, 4, 5, and 5B}

Recent analysis of the testing to date has indicated that under like machine settings and control procedures, marked variations in cutting rates and damage to blade surfaces can be related directly to variations in abrasive concentration.

Marked variations in blade wander can be similarly related to variations in abrasive distribution and blade tension.

The testing was intended to provide extended period cutting rate and abrasive life data, comparisons of slicing performance for different blade sets, and improved machine control procedures.

In slicing with blade sets of impregnated wire from different lots having identical descriptions, variations in cutting performance were experienced.

These variations suggested differences in abrasive concentrations and yield strengths between different lots of the same impregnated wire.

In slicing with four successive blade sets, three sets of blades were chosen from two lots of 0.008 in. diameter copper coated steel wire, impregnated with $45 \mu$ diamonds, and one set was obtained from a lot of 0.008 in. diameter high $\mathrm{Cr}-\mathrm{Ni}$ alloy, wire, impregnated with $45 \mu$ diamonds. 
Blades from the first of the two lots of copper coated steel wire cut consistently with respect to each other and suffered little surface damage during normal cutting procedure.

Blades from the second of these two lots, however, were easily damaged and appeared limited in their ability to achieve uniform, comparable cutting rates.

Blades from the lot of $\mathrm{Cr}-\mathrm{Ni}$ alloy achieved cutting rates comparable to those of the first lot of copper coated steel wire and showed suggestions of possibly superior abrasive life. Blade wander was pronounced in this test, however, and extensive yielding of the wire was apparent during relaxation of the pre-tensioning load.

Because of the differences in performance of the blades from the two lots of copper coated steel wire, these blades were examined under low power magnification and were believed to vary greatly in diamond concentration.

Because of a lack of reliable strength information for all the wire samples and because of the resulting overtensioning of the $\mathrm{Cr}-\mathrm{Ni}$ alloy wire during testing, measured strength data were considered essential.

. In order to confirm these conclusions preliminary blade characterization tests were performed providing hardness and ultimate strength values for samples of used and unused blade materials. Blade base metal compositions and 
some limited surface photography at $300 \mathrm{X}$ and $2000 \mathrm{X}$ magnification were obtained using scanning electron microscopy •

Results of the blade characterization testing showed the two lots of copper, coated steel wire to have been made from two different wire materials. The first lot was made from a low alloy cold drawn steel wire and the second lot was made from a chromium-nickel stainless steel: A third lot which has not yet been used for slicing was also made from a chromium-nickel stainless steel.

The chromium-nickel alloy wire tested in slicing as described above had originally been purchased as stainless stéel. Composition analysis, however, showed it to contain less than 5\% iron, the major constituents being chromium and nickel.

The lower yield strength of this wire and overtensioning of this blade set appeared to have been responsible for tension-related blade wander during testing.

Further interpretation of this data and utilization of improved tension controls referred to above will help to provide clarification of the wander-tension relationship.

Examples of surface photography are presented in Figures 14 through 18. In these photo's no circumferential or longitudinal scans werè made, to cómpare worn and unworn 
areas or to measure uniformity of distribution.

Variations are evident, however, in blade metal damage, diamond concentration, and diamond damage, from one wire sample to the next.

Scale reference bars at the bottoms of the photos are either $10 \mu$ or $100 \mu$ in length, as indicated by the numbers below the bars.

On 300X photos arrows have been used to indicate locations of diamonds which have been magnified to $2000 \mathrm{X}$ in the adjacent photos.

Comparison of photos of $\mathrm{Cu}-\mathrm{stee}$ blades from Lot 1 , Figures 14 and 15, and Lot 2, Figures 16 and 17 (top), shows a dramatic difference in diamond concentration, perhaps 5 or 10 to 1 .

In Figure 17 (bottom) the sample of untested Lot 3 wire contains a large number of indentations where diamonds apparently fell away during processing. For this sample the question arises, how many of the diamonds visible on the surface would remain in place after use.

The same question applied to the unused wire from Lot 2 in Figure 16 (top) is partially answered in Figure 16 (bottom) and Figure 17 (top).

The worn metal area on the blade in Figure 17 (bottom left) is typical of wear observed on blades with low diamond concentration. 


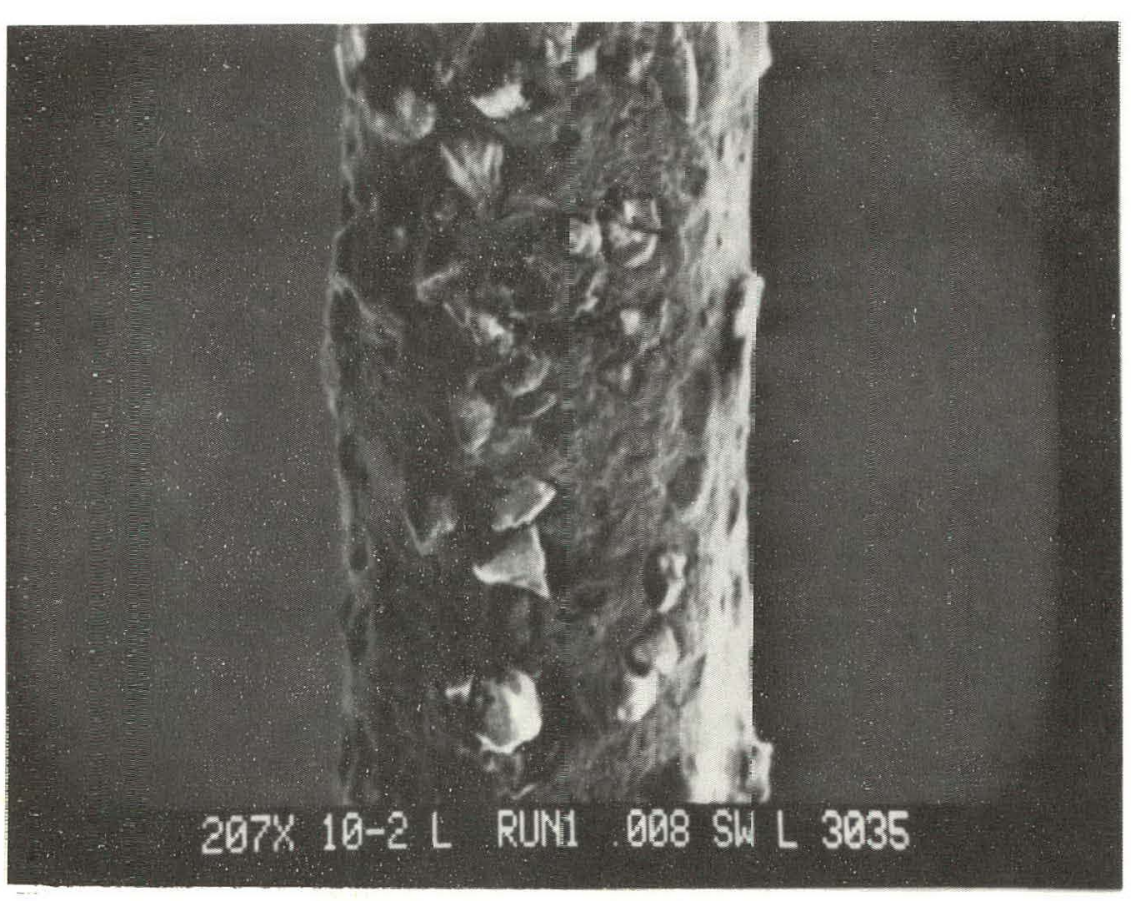

$\stackrel{+}{\infty}$
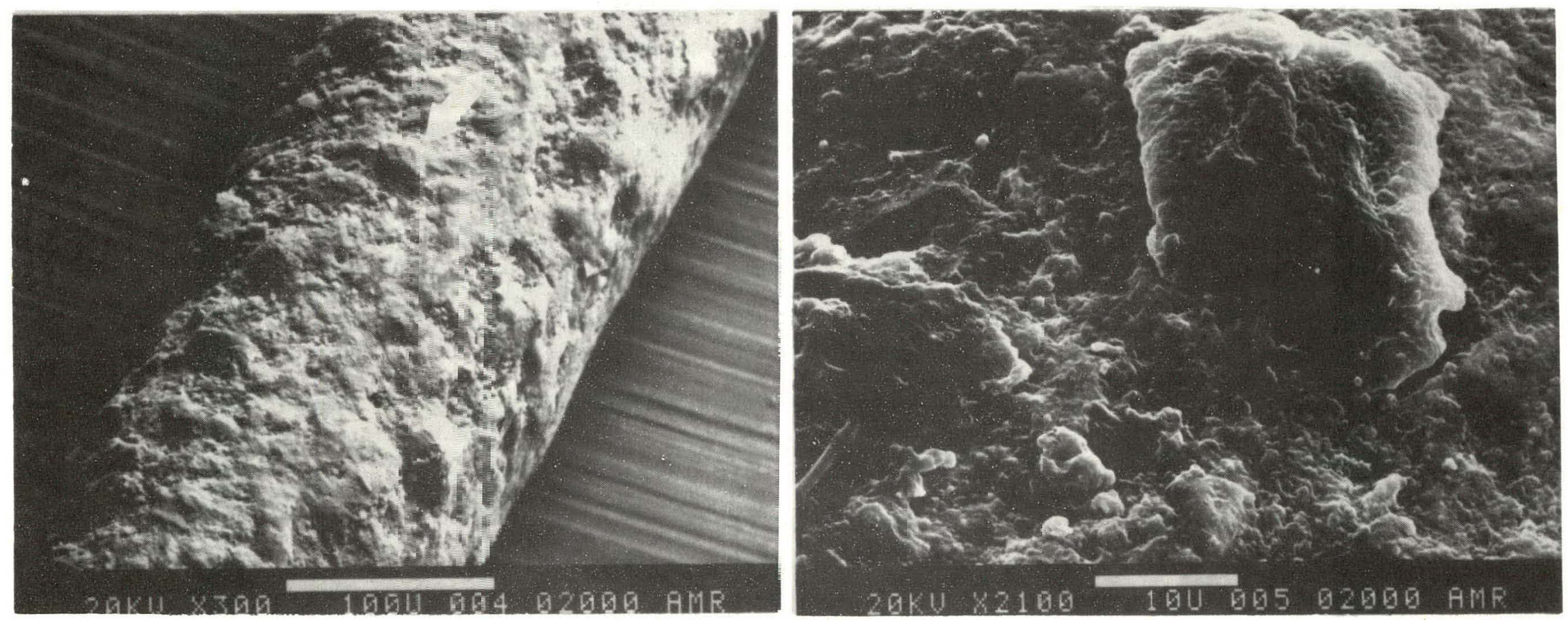

FIGURE 14. 0.CJ8 in D Cu-Stee1 wire, $45 \mu$ dianonds. Lot no. 1. Used, Run 1. 

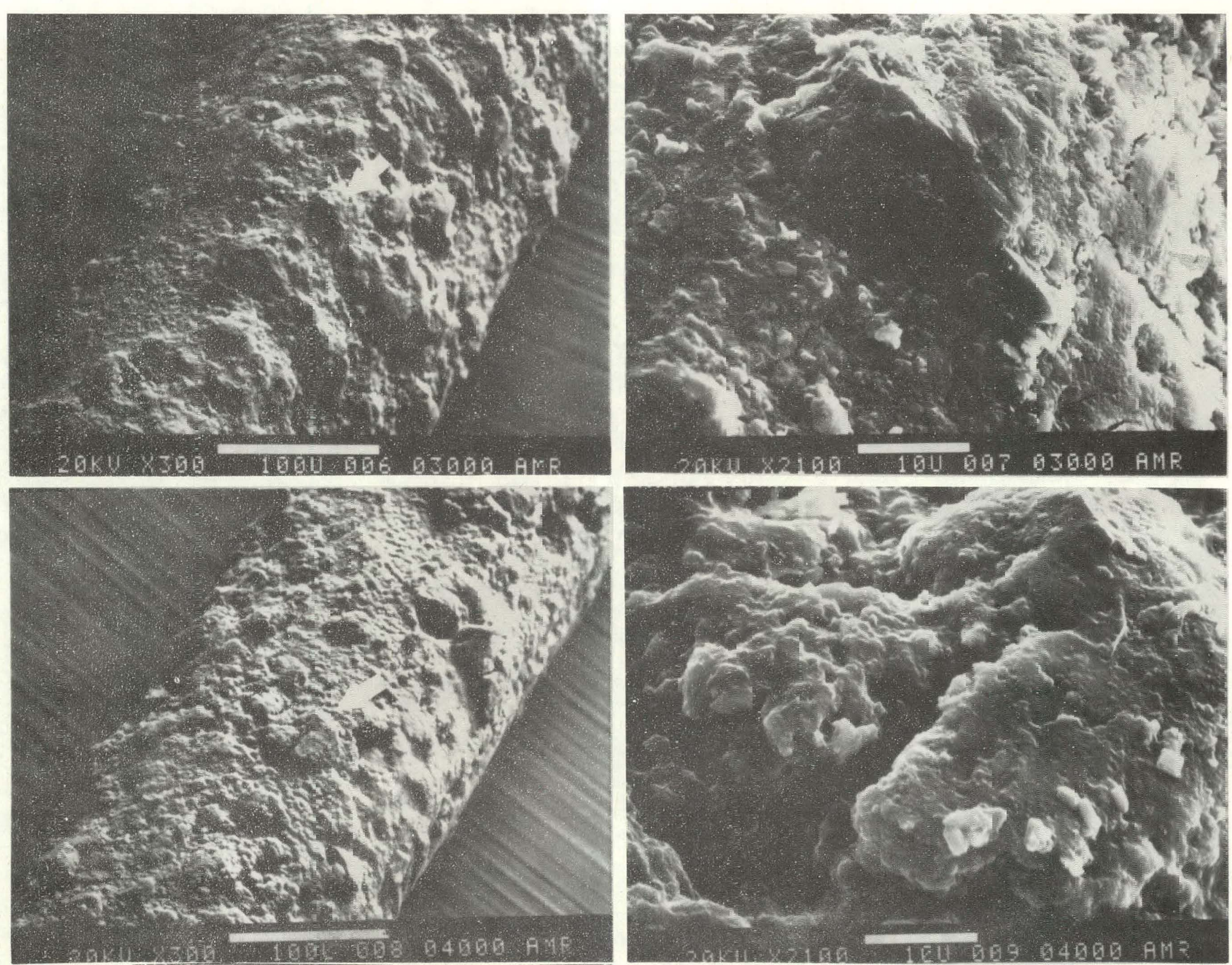

FIGURE 15. 0.008 in $\mathrm{D} \mathrm{Cu-S=eel} \mathrm{wire,} 45 \mu$ diamcnds.

Lot no. 1. Used. (Top) Run 2. (Gottcm) Runs $2 B$ and 3 

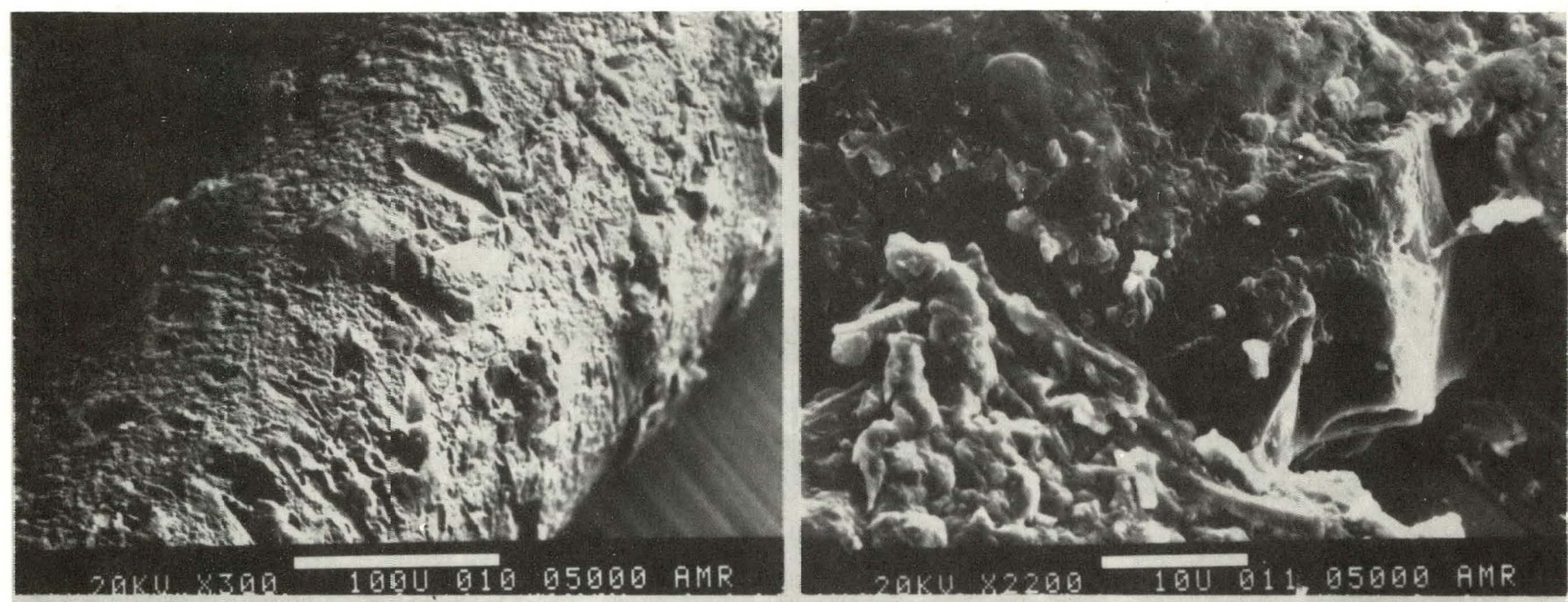

ज
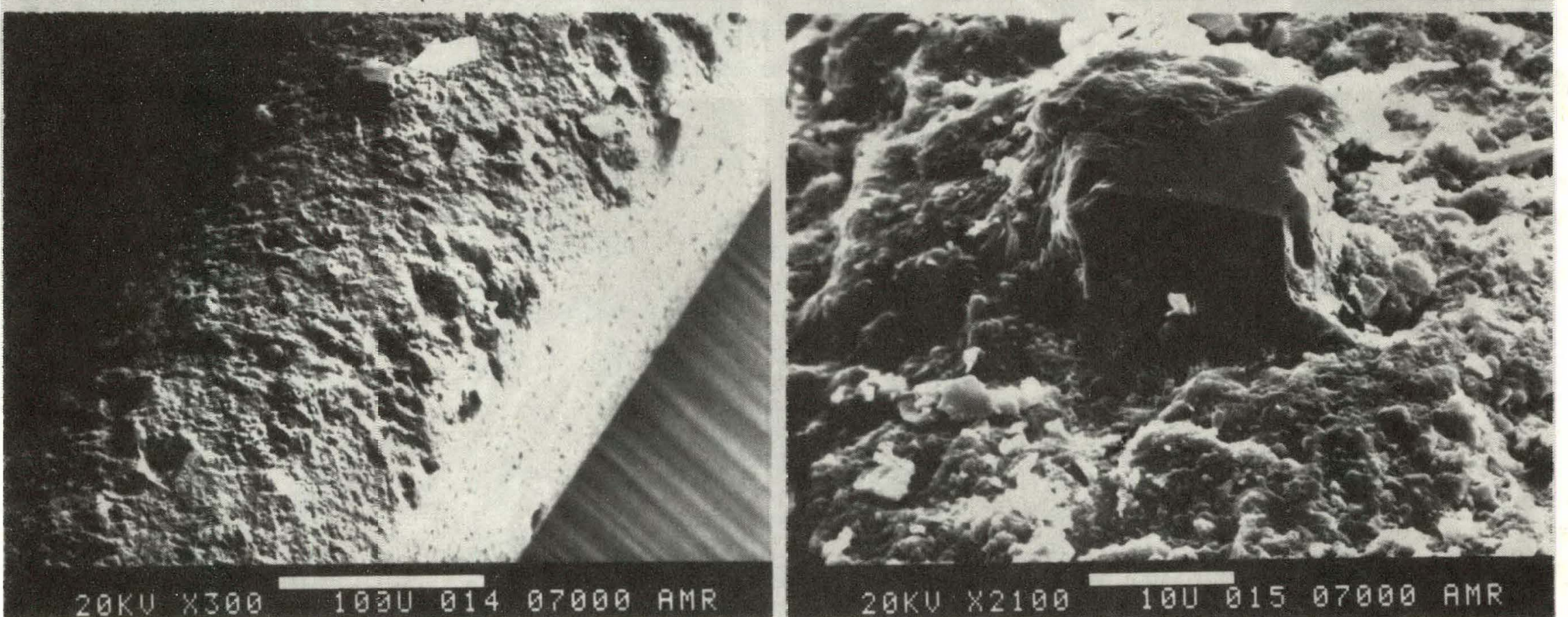

FIGURE 16. 0.008 in D Cu-Steel wire, $45 \mu$ diamonds. Lot no. 2 . ('Top) Unused. (Bottom) Used. Run 4. 

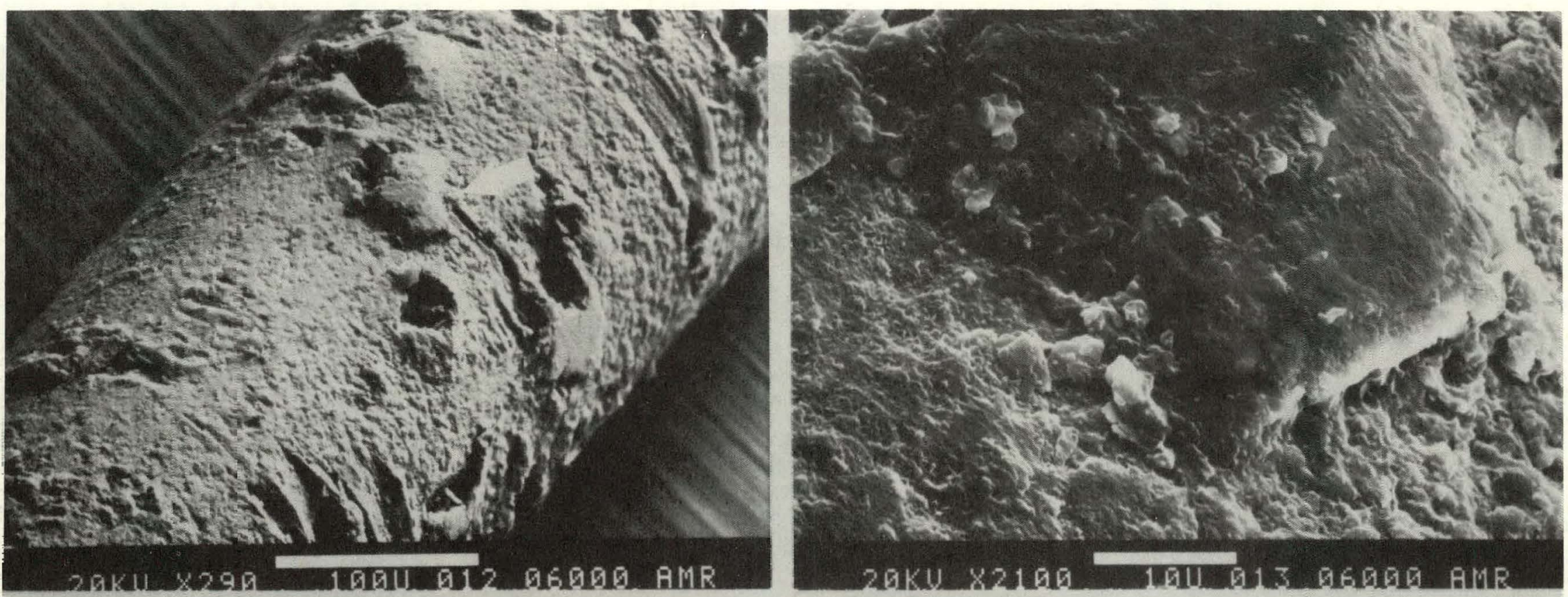

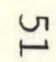
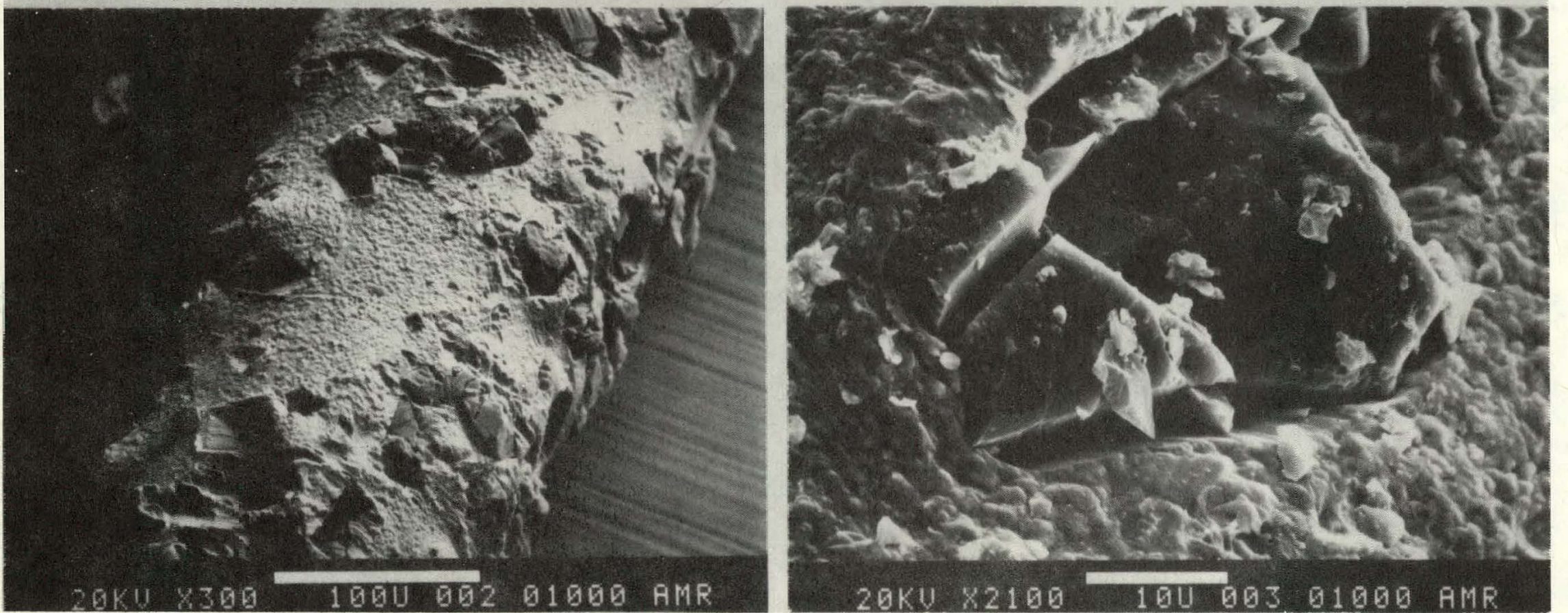

FIGURE 17. 0.008 in $\mathrm{D}$ Cu-Steel wire, $45 \mu$ diamonds.

(Top) Lot no. 2. Used. Run 5. (Bottom) Lot no. 3. Unused. 

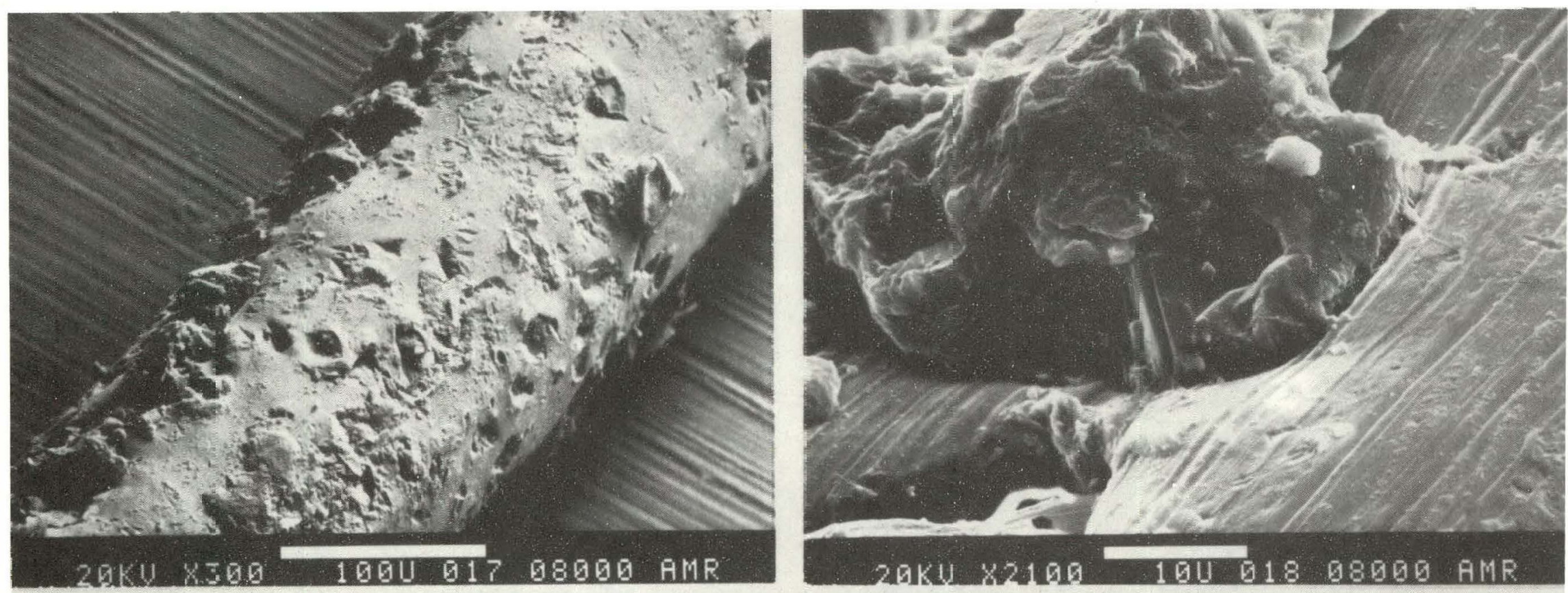

$N$
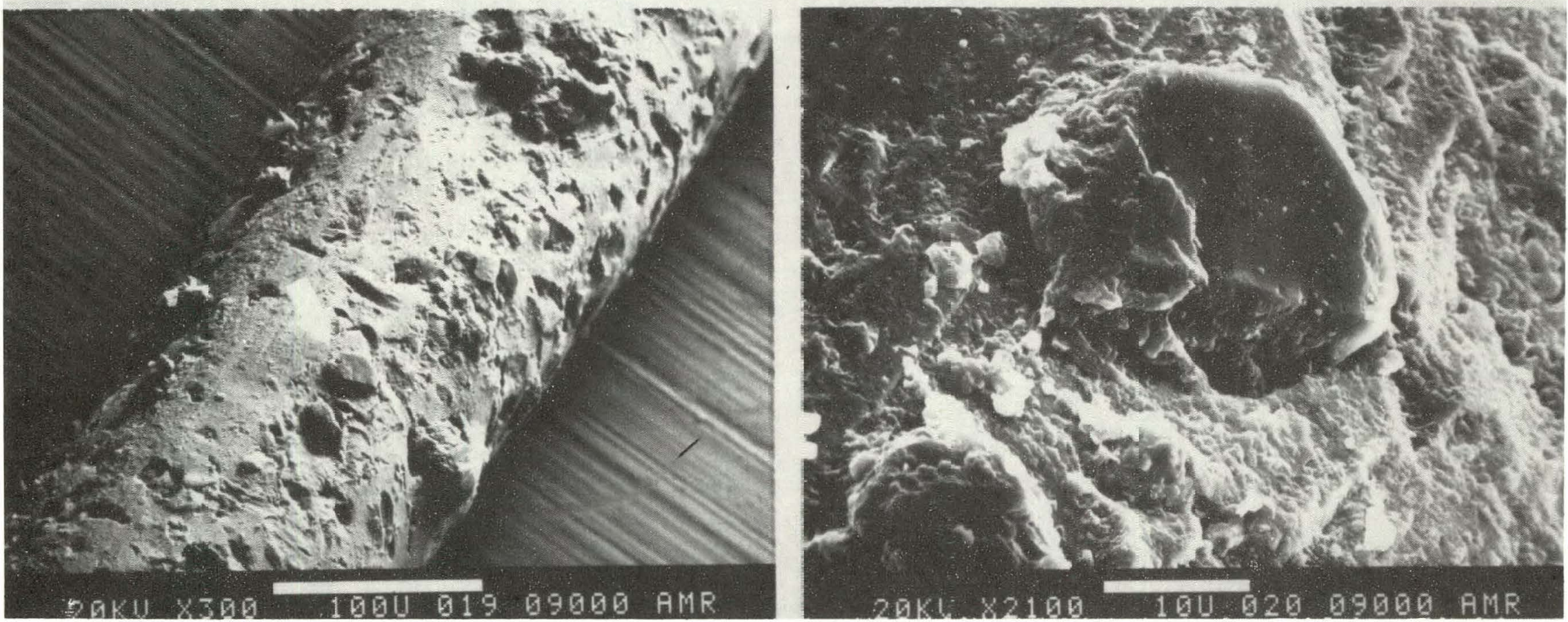

FIGURE 18. 0.008 in $\mathrm{D} \mathrm{Cr-Ni}$ alloy wire, $45 \mu$ diamonds. (Top) Unused. (Bottom) Used. Run 5B. 
Fracturing of diamonds is apparent in the unused sample of Lot 3 wire in Figure 17 (bottom). The 2100X closeup of one of the three or four similarly fractured diamonds suggests that reduction of this type of early diamond damage with an improved blade charging process could improve cutting rate, extend abrasive life, reduce distribution-related blade wander, and improve wafer. surface condition.

The 2100X photos of individual diamonds in Figure 14 (bottom right) and Figure 15 (right top and bottom), and Figure 16 (bottom right) may provide a good comparison between abrasive wear, Figures 14 and 15, and shear fracturing or unused diamond, Figure 16.

For comparison, Figure 16 (top right) and Figure 17 (bottom right) provide examples of unused diamond.

Figure 18 presents similar photos for the chromiumnickel alloy wire which has the same outside diameter and diamond size as the Cu-steel blades in Figures 14 through 17 .

\section{Discussion - Run 6}

As part of the investigation of the diamond charging process, a set of 27 plain 0.008 in. diameter Cu-steel 
wires were charged with $45 \mu$ diamonds.

Of the 27 wires, 19 were charged adequately to cut silicon and were tested on a $1.5 \times 1.5$ inch silicon workpiece for a depth of cut of approximately 0.5 inch.

The cutting rates,- reduced from the data sheet similarly to the Run $2 \mathrm{~B}$ data, are superimposed on the Run $2 \mathrm{~B}$ data, Figure 13.

The cutting rate of 4 mils per minute, for the wires charged in house, compares favorably with the other results.

This in-house charging method appears promising for economically producing high performance diamond impregnated wire blades.

\section{Slicing Procedure}

In slicing with the present wire blades, some changes in cutting rate were observed to occur abruptly while others occurred gradually.

Abrupt changes in cutting rate--most commonly sudden increases--have of ten accompanied step changes in feed force. Typically, associated with such events has been simultaneous damage to blades and wafer surfaces.

More continuous changes in feed force are expected: to result in improvements in these effects.

Improvements in bond strengths between abrasive 
particles and blade metal surfaces is also expected to reduce such damage.

A particularly sensitive transient condition is the startup period, during which an equilibrium cut profile, ${ }^{1}$ such as the one shown in Figure 7 , is being established on a previously square cross section workpiece.

During startup the combination of feed force level, feed force variation with time, machine speed, and perhaps other variables as well must be controlled adequately to avoid abrasive damage.

Elimination of gross variations in blade properties will presumably be possible with improved material inspection, charging procedure, and blade characterization by the manufacturer. Meanwhile, appropriate in-house characterization methods will be used for verification of blade properties.

With in-house blade characterization procedures which are prcsently being implemented, quantitative comparisons will be possible relating cutting performance to abrasive concentration, distribution, fracturing, pullout, and wear, and to machine control procedures.

Improvements in abrasive distribution are expected to result from improved blade charging techniques.

1. Cut profile discussed, pp. 29, 30, 31, ref. 2 . 
Improvements in the control of blade pre-tensioning and feed force, using the present sensitive feed mechanism, recent calibration information, and measured blade material properties, will limit total blade stress to values just below the yield stress. This will reduce tension-related blade wander.

Improvements. in all forms of control in the cutting process are expected to improve wafer surface quality in addition to cutting rate, abrasive life, and blade wander.

The same principles applied to other blade/abrasive combinations: could conceivably offer improvements in those processes as well.

Additional testing over more-extended periods and integration of previous data are expected to provide better identification of cause and effect relationships in cutting performance.

Curve smoothing data reduction techniques are expected to reduce scatter of data points and to yield betterdefined cutting rate and abrasive life values, thus reducing the amount:of testing required. 


\section{CONCLUSIONS}

\section{Silicon Crystal Casting}

1. Lower temperature gradients in the liquid and solid (i.e., lower melt superheat and higher heat-exchanger temperature) have made it possible to achieve good seeding and growth.

2. Single-crystal growth is nucleated from the (111) seed crystal and advances on the (111) in a pyramidal form.

3. In most cases, contaminants mark the interface that exists between the seed and the ingot. The contaminants do not cause breakdown of crystallinity.

4. There is a distinct electrical change from $\mathrm{n}$ - to p-type at the interface. The new-grown silicon has a higher resistivity and becomes p-type due to the doping of the molten silicon by iron from the graphite heat zone.

5. Etch-pit counts of $100 / \mathrm{cm}^{2}$ show the seed and newgrown material to be high crystal quality.

6. All boules fracture across the diameter of the solidified circular ingot on a (111) plane. Secondary fractures occur in some cases on (110) planes. Fracturing occurred during the cool-down cycle at about $650^{\circ}$ due to 
localized tension on the silicon at the crucible interface. Silicon forms a strong bond with the silica crucible which puts it into tension during cool down since its expansion coefficient is 5 times greater than for fused silica.

7. To achieve a high enough heat-exchanger temperature at superheat temperatures below $7^{\circ} \mathrm{C}$, the heat exchanger had to be raised one inch in the heat zone.

8. The temperature profile across the diameter of the heat zone is flatter at the higher position. The flat profile is favorable for growth. Single-crystal growth was achieved across the entire diameter of the crucible.

9. Breakdown of the growth interface occurred when the liquid gradient was too low.

10. The shape of the interface was delineated by breakdown of planar growth.

11. High liquid gradients tend to produce an interface in the shape of a right circular cylinder. Low gradients tend to form a hemispherical interface.

\section{Silicon Crystal Slicing}

12. Cutting rates of from 1 to $4 \mathrm{mil} / \mathrm{min}$ were achieved for feed force from 0.05 to $0.25 \mathrm{lbf} / \mathrm{blade}$.

13. Higher diamond concentration on the cutting edge resulted in higher cutting rate. Low diamond concentration not only resulted in low cutting rates but also blade damage. 
14. Degradation of cutting rate appears to occur more rapidly at the higher feed force; this is currently being related to diamond pull out and waar. 


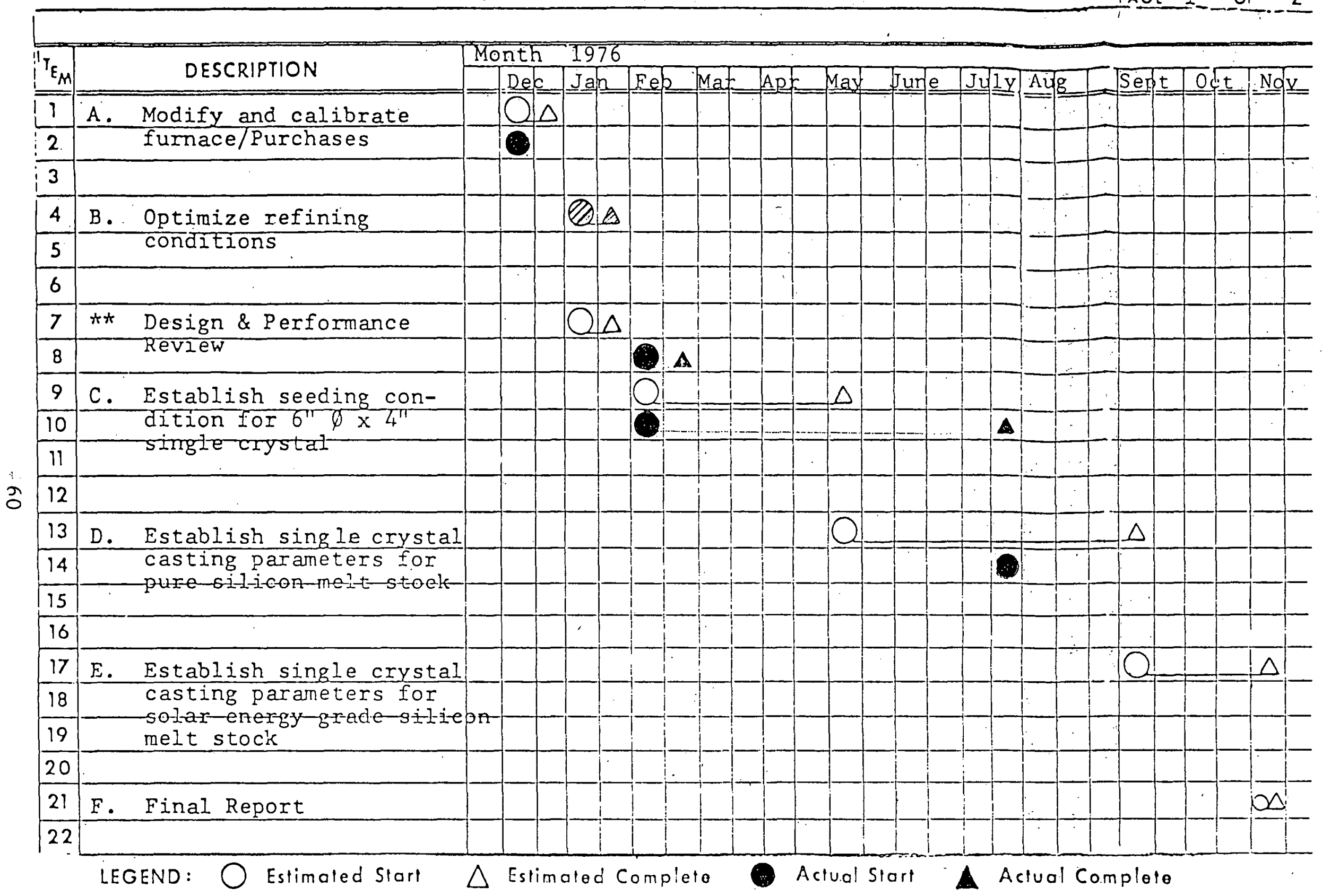

CRYSTAL SYSTEMS, INC.

CONTRACT 非 954373 


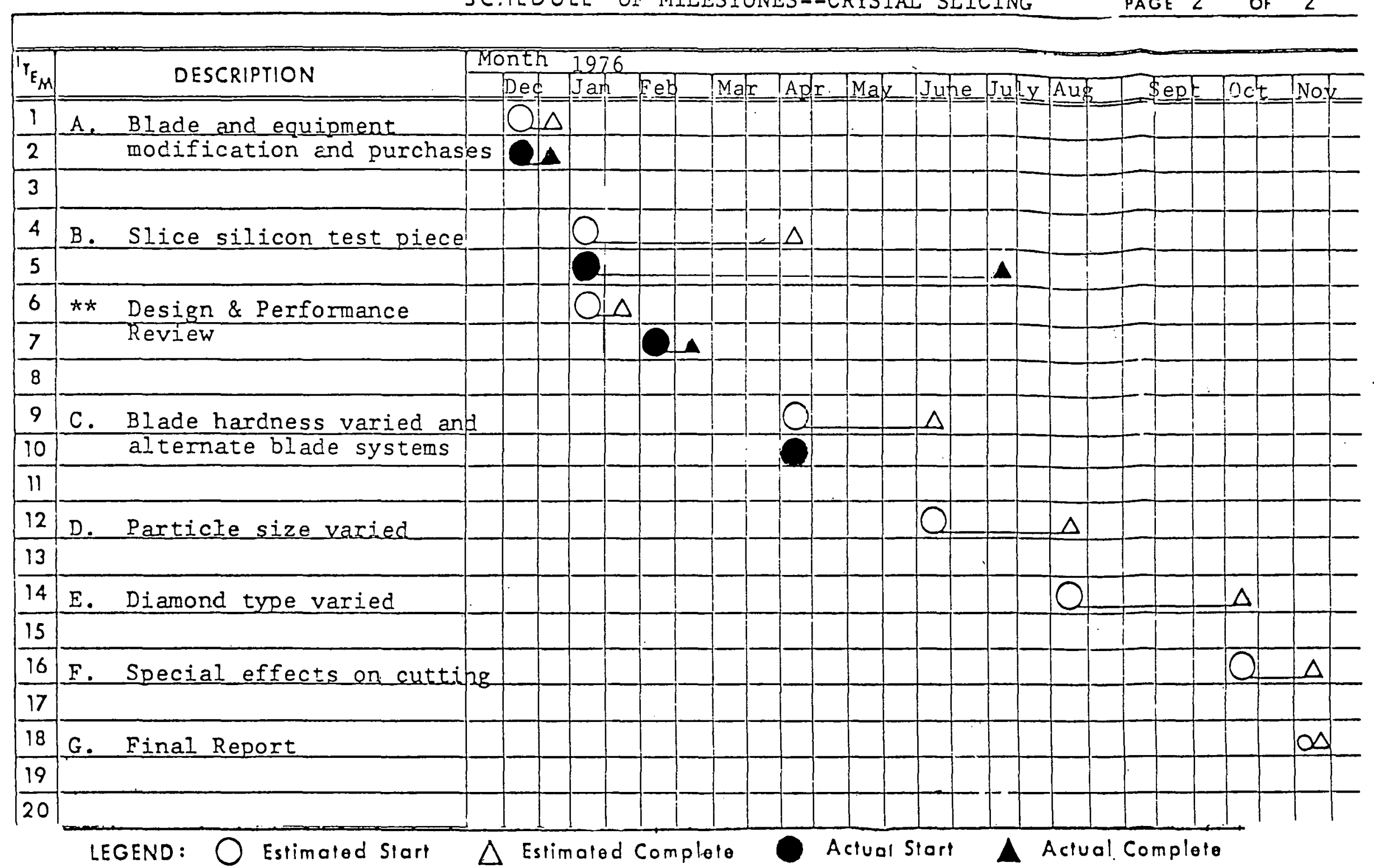

CRYSTAL SYSTEMS, INC. CONTRACT 非 954373 


\section{REFERENCES}

1. J. Hino and H. E. Stauss, "Melting of Undoped Silicon Ingots," J. Metals, Vol. 4, p. 656, 1952.

2. F. Schmid and B. Reynolds, "Heat Exchanger-Ingot Casting/S1icing Process," ERDA/JPL 954373-76/3, Crystal Systems, Inc., Third Quarterly Progress Report, June 1976. 